\title{
Title: The Impact of the Dividend Policy on the Price Volatilization of Common Stock-Evidence from the Stock Market of Hong Kong
}

Author: Wai Tong Kam

Abstract: This paper intends to examine whether a company's policy of dividend would impact or influence the price fluctuation of respective common stock in the designated stock market particularly in Hong Kong. Hence, there are 354 companies in Hong Kong which are all listed company on the Stock Exchange of Hong Kong (HKEX), were chosen as sample data for analysis with their audited financial information ranged from 2001 to 2020. Two proxies, the yield and the ratio of pay-out of dividend were widely adopted for the measurement of the effect of dividend policy and the possible influence on the volatility of respective common stock price by employing two statistical models, which are the model of fixed and random effects to provide accurate regression coefficients. With the results from the model of fixed effects, the yield and the pay-out ratio of dividend have been found statistically associated to the price volatilization of respective common stock in Hong Kong. The statical results in this study also find the yield and the ratio of pay-out of dividend are apparently and negatively associated to the price volatilization of respective common stock in Hong Kong. The research outcomes will be a reference for further study on different variables may have effects or volatilize the price of common stock price particularly in Hong Kong capital market.

Keywords: price volatilization of common stock, dividend policy, yield of dividend, pay-out ratio of dividend, Hong Kong

Contact: kamwaitong@gmail.com

ORCID: 0000-0002-2365-5988 


\begin{abstract}
This paper intends to examine whether a company's policy of dividend would impact or influence the price fluctuation of respective common stock in the designated stock market particularly in Hong Kong. Hence, there are 354 companies in Hong Kong which are all listed company on the Stock Exchange of Hong Kong (HKEX), were chosen as sample data for analysis with their audited financial information ranged from 2001 to 2020. Two proxies, the yield and the ratio of pay-out of dividend were widely adopted for the measurement of the effect of dividend policy and the possible influence on the volatility of respective common stock price by employing two statistical models, which are the model of fixed and random effects to provide accurate regression coefficients. With the results from the model of fixed effects, the yield and the pay-out ratio of dividend have been found statistically associated to the price volatilization of respective common stock in Hong Kong.

The statical results in this study also find the yield and the ratio of pay-out of dividend are apparently and negatively associated to the price volatilization of respective common stock in Hong Kong.

Apart from these, corresponding measurements are conducted on other variables showing the price fluctuation of respective common stock is negatively correlated to the size of enterprise while the price fluctuation of respective common stock is positively correlated to the volatility of earnings. However, the results showed that in Hong Kong capital market, companies' growth rate and the ratio of leverage are not statistically correlated the price volatilization of respective common stock. The research outcomes will be a reference for further study on different variables may have effects or volatilize the price of common stock price particularly in Hong Kong capital market.
\end{abstract}

Keywords: price volatilization of common stock, dividend policy, yield of dividend, pay-out ratio of dividend, Hong Kong 


\section{Table of Contents}

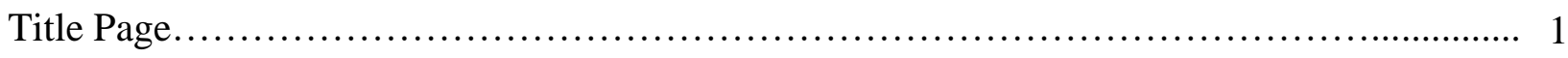

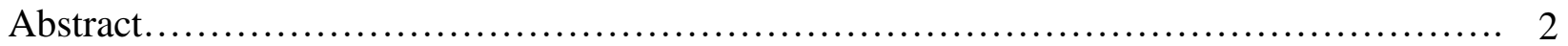

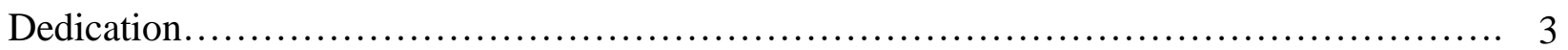

Acknowledgement.............................................................. 4

Table of Contents.............................................................. 5

List of Tables and Figures...................................................... 8

Abbreviations............................................................... 9

\section{CHAPTER I: INTRODUCTION OF THE STUDY}

1.1 Introduction and Background Information...................................... 10

1.2 Problem Statement of the Study ............................................. 11

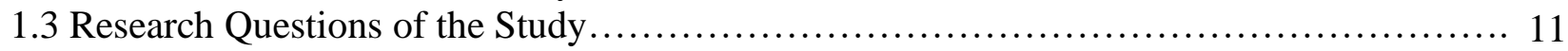

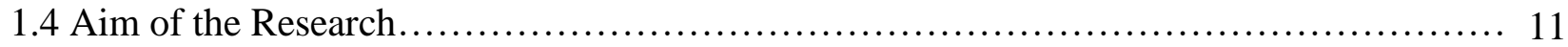

1.5 Objectives of the Study................................................... 11

1.6 Hypotheses Development of the Study......................................... 12

1.7 Organization of Presentation and Framework of the Study $\ldots \ldots \ldots \ldots \ldots \ldots \ldots \ldots \ldots \ldots \ldots \ldots$

CHAPTER II: REVIEW OF RELEVANT LITERATURE

2.1 Review of Relevant Literature............................................... 15

2.2 Theoretical Frameworks Related to the Study .................................... 15

2.2.1 The Theory of Dividend Irrelevance....................................... 15

2.2.2 The Theory of Bird-in-hand.............................................. 15

2.2.3 The Theory of Cost of Being Agency....................................... 16

2.2.4 The Theory of Signaling................................................... 16

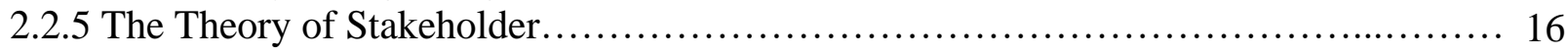

2.2.6 The Effect of Clientele.................................................... 16

2.3 Literature Review Related to the Study........................................ 17

2.3.1 Impact or Influence the Policy of Dividend may have on the Price Fluctuation of Respective Common Stock............................................ 17

2.3.2 Impact or Influence the Size of Enterprise may have on the Price Fluctuation of Respective Common Stock ............................................ 20

2.3.3 Impact or Influence the Ratio of Leverage may have on the Price Fluctuation of Respective Common Stock ............................................ 20

2.3.4 Impact or Influence the Volatilization of Earnings may have on the Price Fluctuation of Respective Common Stock ............................................. 20

2.3.5 Impact or Influence the Growth Ratio of Assets may have on the Price Fluctuation of Respective Common Stock................................................ 21

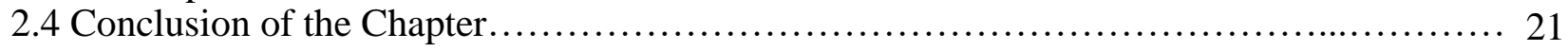

CHAPTER III: DESIGN AND RESPECTIVE METHODOLOGY OF THE STUDY

3.1 Research Design and Respective Methodology .................................. 22

3.2 Research Philosophy and Methodological Approach............................... 22

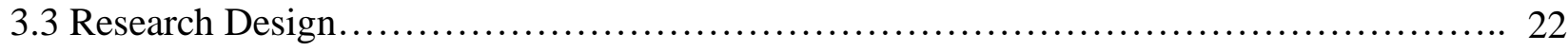


3.4 Variables Applied for the Measurement.......................................... 23

3.4.1 Dependent Variable Applied to the Study................................... 23

3.4.1.1 The Price Volatilization of Common Stock................................ 23

3.4.2 Independent Variables..................................................... 24

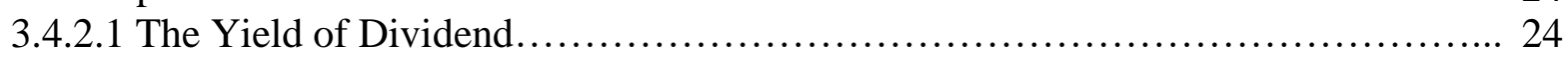

3.4.2.2 The Ratio of Pay-out of Dividend....................................... 24

3.4.3 Control Variables.......................................................... 25

3.4.3.1 The Size of Enterprise............................................... 25

3.4.3.2 The Ratio of Leverage .............................................. 25

3.4.3.3 The Volatilization of Earnings........................................... 25

3.4.3.4 The Growth Ratio of Asset.............................................. 26

3.5 Sampling and Sampling Size................................................. 28

3.5.1 Data Collection Methods and Procedures..................................... 28

3.6 Statistical Methods for Data Analysis ......................................... 28

3.6.1 The Respective Description of Statistics................................... 28

3.6.2 The Analysis Based on Correlation.......................................... 29

3.6.3 The Analysis on Regression............................................... 29

3.7 Research Model Specification and Estimations..................................... 29

3.7.1 Research Model Specification................................................. 29

3.7.2 Estimation Approaches.................................................... 30

3.7.3 Diagnostic Test.......................................................... 30

3.8 Ethical Issues in Research....................................................... 30

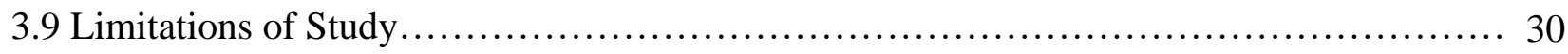

CHAPTER IV: ANAL YSIS OF DATA, RESPECTIVE RESULTS AND DISCUSSION

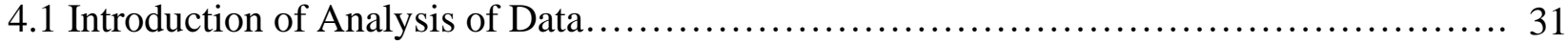

4.2 Treatment of Outliers........................................................ 31

4.3 Descriptive Statistics of Sample Data......................................... 31

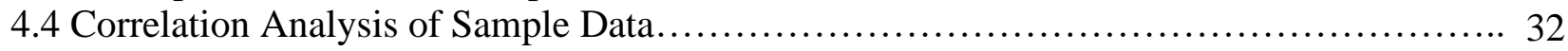

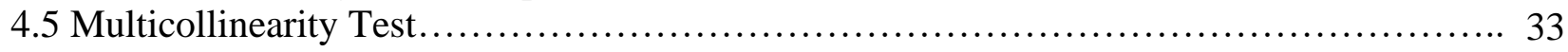

4.6 Panel Data Regression Analysis................................................. 34

4.6.1 F-test and Hausman Test.................................................... 34

4.6.2 Regression Analysis................................................... 35

4.6.3 Adjusted Analysis of Regression........................................ 37

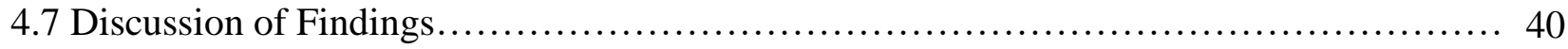

4.7.1 The Correlation between the Yield of Dividend and the Price Fluctuation of Respective Common Stock ............................................... 40

4.7.2 The Correlation between the Pay-out Ratio of Dividend and the Price Fluctuation of Respective Common Stock............................................ 40

4.7.3 The Correlation between Enterprise Size and the Price Fluctuation of Respective Common Stock............................................................... 40

4.7.4 The Correlation between Leverage and the Price Fluctuation of Respective Common Stock............................................................... 41

4.7.5 The Correlation between the Volatility of Earnings and the Price Fluctuation of Respective Common Stock. 
4.7.6 The Correlation between Asset Growth and the Price Fluctuation of Respective Common Stock.

CHAPTER V: CONCLUSION AND RECOMMENDATION

5.1 Respective Conclusion and Recommendation.................................. 43

5.1 .1 Conclusion of Results..................................................... 43

5.1.2 Recommendations......................................................... 44

5.2 Research Limitations.............................................................. 44

5.3 Direction of Future Research................................................. 45

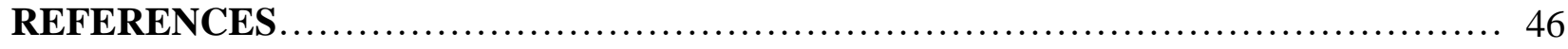

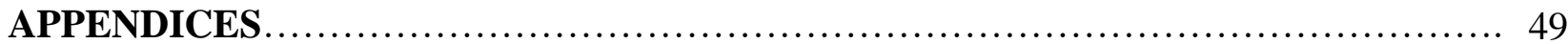

Appendix A - 354 listed companies in Hong Kong (samples of observation) ............... 49 


\section{List of Tables and Figures}

Table 3.1: Summary of Measurement of Adopted Variable in Research................... 27

Table 4.1: Descriptive Statistics............................................. 32

Table 4.2: Spearman Correlation.................................................. 33

Table 4.3: Multicollinearity Test............................................... 34

Table 4.4: The Statical Outcomes of Hausman Test and F-test........................ 35

Table 4.5: Regression Analysis of Fixed Effects Model and Random Effects Model........ 37

Table 4.6: Adjusted Results of Regression Analysis................................ 38

Table 4.7: Summary of Hypothesis Results...................................... 39 


\section{Abbreviations}

ASE - $\quad$ Stock Exchange of Amman

CAPM - Capital Asset Pricing Model

DPR - The Pay-out Ratio of Dividend

DSE - $\quad$ Stock Exchange of Dhaka

DY - The Yield of Dividend

EBIT - Profit Before Interest and Tax

EV - The Volatility of Earnings

FEM - Fixed Effects Model

GRO- Asset Growth

HKEX - Stock Exchange of Hong Kong

HNX- Stock Exchange of Hanoi

HOSE - Stock Exchange of Hochiminh

KLSE - Stock Exchange of Kuala Lumpur

KSE - $\quad$ Stock Exchange of Karachi

LEVE - Leverage

PVOL - The Volatility of Common Stock Price

REM - Random Effects Model

SIZE- Enterprise Size

TSE - $\quad$ Stock Exchange of Tehran

VIF - Variance Expansion Factor 


\section{CHAPTER I: INTRODUCTION OF THE STUDY}

\subsection{Introduction and Background Information}

"A dividend policy is the policy a company uses to structure its dividend" (James, 2020). Investors always take into consideration of companies' dividend policy proxied by the ratio of pay-out and the yield of dividend to be the vital determinants when deciding on stock investment. Meanwhile, these determinants are treated as the important factor to the management of the company on the estimation of future reinvestment, common stock price movement and the shareholder's wealth.

It has been a long-arguing topic concerning whether the policy of dividend would affect the fluctuation of respective common stock price since a similar study primarily carried out by Black and Scholes (1974) with the empirical results showing no relationship exists in between.

In 1989, Baskin (1989) argues that a company's price volatilization of its common stock price is apparently driven by the policy and regulation towards dividend payment which is proxied by two major factors, namely the yield and the pay-out ratio of dividend, with a negative direction in his research. The findings of researches conducted by Hashemijoo et al., (2012) later in 2012 in Malaysia is firstly found to be consistent with the Baskin (1989) regarding the possible impact that a company's policy, strategy and regulation regarding dividend payment causes the price volatilization of corresponding common stock. Later Ramadan (2013) in Jordan in 2013, both Sew et al., (2015) and Zainudin et al., (2018) in Malaysia and Shah and Noreen (2016) in Pakistan are also in unanimous agreement with Baskin (1989).

However, the results from Allen and Rachim (1996) in Australia are just partially consistent with the findings of Baskin (1989) with the observation of the fluctuation of common stock price that is driven by the pay-out ratio of dividend in a negative way. Other researchers including Nazir et al., (2010) in Pakistan, the researcher, Hussainey et al., (2011) in United Kindom, Al-Shawawreh (2014) in Jordan, two researchers, Lashgari and Ahmadi (2014) jointly found the same outcomes in Iran.

Following similar analytical framework of Baskin (1989), the empirical studies alike are conducted in various sectors, markets and geographical locations across developing and developed countries such as Malaysia, Pakistan, Iran, Jordan, Bangladesh, Vietnam, United States, United Kingdom and Australia. However, the empirical results from these studies are not consistent. The Stock Exchange of Hong Kong (HKEX), being the largest bourse worldwide regarding the size of market capitalization with 2,538 companies go public as of the fiscal year end of 2020, up to this point, there is no research particularly on how the company's policy or regulation towards dividend payment fluctuates the price of respective common stock in Hong Kong.

Our hypothesis presents the empirical results of the possible influence or impact of dividend policy may have and how it fluctuates the corresponding common stock price particularly towards the companies which are currently go public on HKEX in order to provide investors an important reference when making investment decisions. 


\subsection{Problem Statement of the Study}

The similar researches conducted in various sectors, markets and geographical locations across developing and developed such as Malaysia, Pakistan, Iran, Jordan, Bangladesh, Vietnam United States, United Kingdom and Australia. However, there are no unanimous findings on the impact or influence that dividend policy proxied by the yield and the pay-out ratio of dividend, may have on how it fluctuates the price of common stock, and these similar studies are concluded in the past. In addition, there is absence of similar research perform in the stock market of Hong Kong.

\subsection{Research Questions of the Study}

The question in this research is whether dividend policy would affect the volatility of common stock price particularly in Hong Kong stock market. To be more specifically, could the dividend policy affect or fluctuates the price of common stock? In addition, could other variables including size, leverage, the volatility of earnings and asset growth affect or fluctuate the price of common stock as well? These major questions will be examined and discussed in this hypothesis.

\subsection{Aim of the Research}

Our intention is to provide an importance reference to investors of listed companies in Hong Kong stock market in this study in order to have insight on the effect of the company's policy or regulation towards dividend payment and how it volatilizes or fluctuates the price of corresponding listed stock when they are necessary to marking investment decision.

\subsection{Objectives of the Study}

This paper is to assess and have a thorough understanding of the possible impact that the company's policy or regulation towards dividend payment on the volatilization or fluctuation of respective price of common stock particularly in Hong Kong stock market.

Even though lots of researchers conducted assessment of the how dividend policy may affect the price fluctuation of respective common stock across countries that possesses their owned stock exchange worldwide in the past. With no empirical studies conducted in the past, this research will, therefore, become the first study to especially examine how dividend policy influences the price volatilization of respective common stock particularly towards Hong Kong stock market, taking 354 listed companies that have sufficient financial data from 2001 to 2020 in HKEX to be the sample data for analysis. Specific objectives are stated as follow:

1. To inspect whether the yield of dividend is significantly correlated with the price fluctuation of common stock;

2. To inspect whether the ratio of pay-out of dividend is significantly associated to the price fluctuation of common stock; 
3. To inspect whether the size of enterprise is significantly correlated with the price fluctuation of common stock;

4. To inspect whether the leverage is significantly correlated with the price fluctuation of common stock;

5. To inspect whether the volatility of earnings is significantly correlated with the price fluctuation of common stock;

6. To inspect whether the rate of growth is significantly correlated with the price fluctuation of common stock.

\subsection{Hypotheses Development of the Study}

The research problem, questions, aim and objectives are clearly identified in the previous sections, hypotheses are then to set up for examination as follows:

Dividend policy is how much of earnings the company makes to pay out to shareholders as dividends or retain in the company as reinvestment. Among all previous studies, researchers conducted similar studies have different views on the possible impact or influence of relevant regulation or policy of the company concerning dividend payment that may have on the price fluctuation of respective common stock in designated stock markets. Some researches revealed the price volatility of common stock in designated stock markets is driven by the yield of dividend with the positive correlation, while some found the price of common stock in designated markets is being fluctuated by the pay-out ratio of dividend with the negative correlation. In addition, some studies revealed the yield and the pay-out ratio of dividend are significantly and negatively correlated to the volatility of common stock price. In this study, it extends the hypothesis to be tested in Hong Kong stock market as follows:

\section{Hypothesis 1}

$\mathrm{H}_{1 \mathrm{a}}$ : The yield of dividend is significantly correlated to the price fluctuation of common stock of companies go public in HKEX.

$\mathrm{H}_{1 \mathrm{~b}}$ : The yield of dividend is not significantly correlated to the price fluctuation of common stock of companies go public in HKEX.

\section{Hypothesis 2}

$\mathrm{H}_{2 \mathrm{a}}$ : The pay-out ratio of dividend is significantly correlated to the price fluctuation of common stock of companies go public in HKEX.

$\mathrm{H}_{2 \mathrm{~b}}$ : The pay-out ratio of dividend is not significantly correlated to the price fluctuation of common stock of companies go public in HKEX.

Secondly, smaller companies usually experience more volatility on common stock price compared to larger companies, which is mainly attributable to the greater uncertainty in terms of operational competitiveness and profitability of smaller companies, intensifying the fluctuations of common stock price. In this study, it extends the hypothesis to be tested in Hong Kong stock market as follows: 


\section{Hypothesis 3}

$\mathrm{H} 3 \mathrm{a}$ : The size of enterprise is significantly correlated to the price fluctuation of common stock of companies go public in HKEX.

$\mathrm{H} 3 \mathrm{~b}$ : The size of enterprise is not significantly correlated to the price fluctuation of common stock of companies go public in HKEX.

Thirdly, due to the fact that dividends to be paid to shareholders will be after interest payment, the increase in leverage may decrease the dividends received by shareholders, and thereby the volatility of common stock price will probably be affected by the leverage. In this study, it extends the hypothesis to be tested in Hong Kong stock market as follows:

\section{Hypothesis 4}

H4a: The leverage is significantly correlated to the price fluctuation of common stock of companies go public in HKEX.

H4b: The leverage is not significantly correlated to the price fluctuation of common stock of companies go public in HKEX.

Fourthly, the more stable the price fluctuation of common stock, the more stable the company's earnings. Partial earnings will be transformed into dividends paid to shareholders. Higher earnings mean of the company could mean higher dividends possibly. In this study, it extends the hypothesis to be tested in Hong Kong stock market as follows:

\section{Hypothesis 5}

H5a: The volatility of earnings is significantly correlated to the price fluctuation of common stock of companies go public in HKEX.

$\mathrm{H} 5 \mathrm{~b}$ : The volatility of earnings is not significantly correlated to the price fluctuation of common stock of companies go public in HKEX.

Lastly, the growth of asset requires companies to invest into tangible assets continuously and the remaining cash after dividends paid to shareholders will be retained earnings as reinvestments to the company. As such, the growth of asset is supposed to have certain association existed with the price fluctuation of respective common stock. This study extends the hypothesis to be tested in Hong Kong stock market as follows:

\section{Hypothesis 6}

H6a: The growth of asset is significantly correlated to the price fluctuation of common stock of companies go public in HKEX.

H6b: The growth of asset is not significantly correlated to the price fluctuation of common stock of companies go public in HKEX. 


\subsection{Organization of Presentation and Framework of the Study}

There are five major chapters and several sub-chapters are presented in our hypothesis in order to provide exhaustive discussion and understanding of how the company's policy or regulation regarding dividend payment to its stockholders may impact or influence the price fluctuation of respective common stock particular on the designated stock exchange in Hong Kong. It starts with first chapter introduces the background information, respective problem statement, the purpose, the questions, the aim, the objectives, the development of specified hypotheses, along with the organization of presentation at the end. Chapter 2 included the theoretical framework applied to this research and relevant literature reviews. The design of this research will be discussed in Chapter 3 with variables, sampling, analytical tools involved. Chapter 4 provided detailed data analysis and its outcomes and Chapter 5 consists of the conclusions and recommendations of this study. 


\section{CHAPTER II: REVIEW OF RELEVANT LITERATURE}

\subsection{Review of Relevant Literature}

Prior to the further discussion or knowing the specific elements or factors to be assessed, it is utmost necessary to identify the linkage that may be possibly exists between the regulation or policy of the company towards the payment of dividend, and the price volatilization of respective common stock. With this Chapter, relevant theoretical frameworks contain essential theories are explained in detailed through reviews related to our topic before moving on the next part, the design of this research.

\subsection{Theoretical Frameworks Related to the Study}

Relevant theorical frameworks contains a series of theories are explained in this part, namely the commonly seen theory of the irrelevance of dividend indicating no relationship is found between dividend and the price of designated common stock, along with the other popular theories within the field of financial studies including bird-in-hand, cost of being agency, signaling and the theory of stakeholder as well as clientele effect, have been dominated in this field of study and guide me through the whole research.

\subsubsection{The Theory of Dividend Irrelevance}

Firstly, raised out by both researchers, namely Miller and Modigliani (1961), the irrelevance of dividend policy to common stock price was pointed out, since dividends are only considered as cash payments from the earnings of the companies rewarding to its investors. The assumption in this theory is by the companies' paying 100 percent of their earnings and the existence of perfect capital markets meaning there is no fee including transaction cost and tax, all investors are assumed to be rational investors with investment in stocks according to the actual worth of the stock meaning it is based on the cash flow in the future to be discounted into currently value, as well as no single buyer or seller could affect the price of market, which is almost impossible in reality in the current situation of capital markets.

\subsubsection{The Theory of Bird-in-hand}

Even since the released of the theory of dividend irrelevance which demonstrated no significant influence from the company's dividend to its respective price of common stock, researchers conducted similar studies in this field have been arguing and perform test on relevant hypotheses to prove the significant influence of dividends on common stock price in imperfect capital markets. Not in agreement with the theory of dividend irrelevant, Gordon and Shapiro (1956) and Lintner (1962), pointed out that investors prefer certainty by receiving cash dividends instead of uncertain capital gains due to market uncertainty and asymmetric information, and invented the respective theory called, the theory of Bird-in-hand.

This theory revealed that companies to pay higher dividend in order to maximize the common stock price concerning the certainty of dividends brought to investors, making the company's policy or regulation towards dividend payment fluctuates and volatilize the price of respective common stock in the imperfect capital markets. In addition, dividends are expected to be a signal of future cash flows. 


\subsubsection{The Theory of Cost of Being Agency}

Meckling (1976) raised out the theory together with Jensen (1976) revealed that a cost exists between shareholders and management due to conflict of interest, called the theory of cost of being Agency. It argues that management tends to act in their own interest and this is considered a cost existing between management and stockholders, for instance, management would have less cash or idle funds to reinvest into the new projects after cash dividends to stockholders, making managers into dilemma in terms of new project development and arrangement required cash injection. As such, this theory supports that the ratio of pay-out of dividend apparently drives and fluctuates the value of the companies' common stock.

\subsubsection{The Theory of Signaling}

Signaling theory argues that due to asymmetric information, investors use dividends to be a signal reflecting as an indication of companies' future prospects. For instance, an increase in the pay-out ratio of dividend could signal a positive future development of the company. According to Petit (1972), it is observed that common stock price is affected by dividend payment to investors and dividend is considered as a vital information of companies' future prospects.

\subsubsection{The Theory of Stakeholder}

In consistent with signaling theory, the theory of stakeholder also suggests that dividends carry and provide information of companies' profitability and future financial competency to stockholders.

\subsubsection{The Effect of Clientele}

According to Lewellen et al., (1978), the effect of clientele indicated that interests are varied from different group of customers and thereby changes in dividend policy would lead to dissatisfaction on partial customers, ultimately caused negative effects on the price of stock.

In addition, Al-Malkawi (2007) pointed out a particular phenomenon that lesser dividends are expected to be distributed from the enterprise pays to its shareholders especially when the enterprise is under the stage of fast-grow period. However, the situation turned around when it goes to the stage of maturity. These two stages attract clientele desire capital gains and immediate cash income from dividends respectively. So that, the company's dividend policy would have significant influence and volatilize the price of its common stock. 


\subsection{Literature Review Related to the Study}

There are continuous studied on the elements moving the volatility of common stock price. Among all these studies, the results are varied as some of them are consistent with each other, while some studies are not similar due to the sample used to analysis across various sectors and countries. Although studies conducted in the same country, the identified variables that are concluded to have significant or insignificant influence on the volatility of common stock price are not reached to a mutual agreement with each other. Prior to the research methodology, a thorough review is performed on previous studies as follows:

2.3.1 Impact or Influence the Policy of Dividend may have on the Price Fluctuation of Respective Common Stock

The examination of the influence or impact that the policy or regulation of the company regarding dividend payment may have on the price fluctuation of respective common stock, were carried across various sectors including financial or non-financial companies, as well as developed or developing countries with similar variables but dynamic results.

First or all, similar researches are carried out earliest by American, Australian and British researchers, providing a primary reference and a solid ground for all later researchers studied whether the policy or regulation of the company would have on the price volatilization of respective common stock. In 1974, by taking a number of 25 chosen companies which go public in the Stock Exchange of New York, and with the application of capital asset pricing model (CAPM) during mathematical analysis, Black and Scholes (1974) concluded that the policy of the company is not significant enough to fluctuates or volatilized the price of respective common stock, with the length of 30 years during the time period from 1936 to 1966.

Later in 1989, by taking a larger sample data of selected companies totaling 2,344 in United States with the time period of 20 years from 1967 to 1986, Baskin (1989) performed the relatively similar examination on the connection between the policy of the company towards dividend payment and the price volatilization of respective common stock. Compared to the previous, the main difference is the employment of regression model to perform analysis instead of capital asset pricing model (CAPM) by Black and Scholes (1974). His research carried out by using the price fluctuation of respective common stock, the ratio of pay-out and the yield of dividend which are proxies of dividend policy, to be the dependent and independent variables respectively, and the results indicated the policy of the company towards dividend payment would volatilize and fluctuation the price of respective common stock price but with the association in negative way. Other controls variables are also appeared in this study and they are the size of enterprise, the ratio particular calculated for the long-term portion of debt, the volatilization of company's earnings as well as the growth ratio of company's asset. The study provided a crucial analytical framework for following related studied on the association or correlation that the policy of the company towards dividend payment may have, to the fluctuation the price of respective common stock price.

Later in 1996, both Australian researchers, Allen and Rachim (1996) rejected the hypothesis released by Baskin (1989) and discovered that the pay-out ratio of dividend is significantly positive correlated to the price fluctuation of respective common stock, meanwhile, the yield of dividend is not significant enough 
to have association with the price fluctuation of corresponding common stock price, taking companies totaling 173 that go public in the stock exchange of Australia with the length of time from 1972 to 1985. The measured variables included are the same variables following the same framework of Baskin (1989) to analysis.

British researcher, Hussainey et al., (2011) has the close results compared to Baskin (1989) with the research carried out in 2011 and companies in United Kingdom with a length of 10 years from 1998 to 2007. His observation revealed that the yield of dividend, in a certain extent, is associated with the price fluctuation of respective common stock with a negative direction, but statistically insignificant. Meanwhile, the ratio of pay-out of dividend is identified to drive the price volatilization of respective common stock with the observation of negative direction. Similar variables including size, debt, the volatility of earnings and asset growth are measured in this study.

In 2013, American researches, namely Profilet together with Bacon (2013) conducted studies in the same country as Baskin (1989), with samples of 599 listed companies taken from S\&P 500 over the course of three years. In contrary, the findings are not supporting the results of Baskin (1989), with the ratio of payout of dividend is found to be statistically correlated with a positive direction, with price fluctuation of respective common stock but insignificantly. The results for the yield of dividend is the other way around, showing it would affect the price fluctuation of corresponding common stock but with the negative direction which is in alignment with the results of Baskin (1989).

In context of studies in developing countries, by taking companies totaling 73 that are not financial institution and go public in the stock exchange of Karachi (KSE) and the time period for analysis from 2003 to 2008, Nazir et al., (2010) firstly performed his research in Pakistan, the yield of dividend is concluded to affect the price volatilization of respective common stock with a positive association observed in between. It is the same to the ratio of pay-out of dividend but with a negative direction is observed. In contrast, by taking 50 non-financial listed companies across 11 industrial sectors on KSE and a length of 8 years from 2005 to 2012, Shah and Noreen (2016) observed that both the yield and the ratio of pay-out of dividend would drive the price volatilization of respective common stock with a negative association linkage is identified in between. Based on the sample data of financial related enterprises totaling 63 that go public in KSE with a time period from 2006 to 2011 accounted for 6 years, Hamid et al., (2017) raised out that the yield of dividend significant affect the price volatilization of respective common stock with a negative direction, this is the same to the ratio of pay-out of dividend but it comes with a positive correlation in between.

In 2014, both Iranian researchers, namely Lashgari and Ahmadi (2014) conducted hypothesis and came out with statistical outcomes showing possible influence that the company's policy towards dividend payment on the price fluctuation of respective common stock without consideration of the yield of dividend to be the variable in his research. A sample data contains companies totaling 51 that go public in Tehran Stock Exchange (TSE) of Iran and a length of time period of 6 years from 2007 to 2012. The findings of their research found the ratio of pay-out of dividend would drive the price fluctuation of respective common stock in a negative way. 
Malaysian researcher, Hashemijoo et al., (2012) concluded that the policy of the company regarding dividend payment was identified to affect and influence the price volatilization of respective common stock price in his research. In his study, Malaysian enterprises totaling 84 and go public in the stock exchange of Kuala Lumpur (KLSE) were chosen to the samples and a length of 6 years from 2005 to 2010 was selected. Sew et al., (2015) who selected 319 listed companies on KLSE and a length of 11 years from 2003 to 2013, and Zainudin et al., (2018) who chose 166 industrial product companies listed on KLSE with data of 10 years from 2003 to 2012, observed the consistent results that the yield and the ratio of pay-out of dividend would influence the price volatilization of respective common stock price with the negative significance being observed in the study.

With the selection of companies totaling 77 that go public in the stock exchange of Kuala Lumpur, Malaysian researcher, Zakaria et al., (2012) raised out a mixture of statistical findings, which is the yield of dividend merely drives the price volatilization of respective common stock with a negative direction, but not consistent with the results for the ratio of pay-out of dividend showing it is positively linked with the price fluctuation of respective stock in this study.

Furthermore, the findings in other countries like Jordan, Bangladesh and Vietnam are varied. In the market of Jordan, by taking enterprises totaling 77 which are in the industrial industry and go public in the stock exchange of Amman (ASE) during the period from 2000 to 2011, Ramadan (2013) proved that the company's policy regarding dividend payment would drive the price fluctuation of respective common stock in his hypothesis with a positive linkage is observed. However, Al-Shawawreh (2014) only partially supports the findings of Ramadan (2013), with only the ratio of pay-out of dividend is significant enough to affect the price fluctuation of respective common stock, by taking 53 companies on ASE with a length of 13 years from 2001 to 2013.

In the market of Bangladesh, taking the sample financial data from companies totaling 35 particularly towards the industry of manufacture in the Stock market of Dhaka (DES) and 11-year data during the time period from 2004 to 2014, Haque et al., (2019) revealed that the yield of dividend is significant enough to drive the price fluctuation of respective common stock with negative direction is observed. Meanwhile, Vietnamese researchers, Anh and Nhi (2016) found a completely different results compared to most of the results by conducting their research on 165 companies go public in Vietnam with yield and the ratio of payout of dividend to be associated with the price volatilization of respective common stock with a positive direction. However, in Hochiminh Stock Exchange (HOSE) in Vietnam, Nguyen et al., (2020) found a mixture of statical outcomes, that is, the yield of dividend drives the price fluctuation of respective common stock with a positive direction, but the ratio of pay-out of dividend comes with the opposite direction. 
2.3.2 Impact or Influence the Size of Enterprise may have on the Price Fluctuation of Respective Common Stock

Black (1976 a, b) firstly found that the size of enterprise size is associated to the price volatilization of common stock with the negative direction. Later in 1982 and 1992, both Christie (1982) and Cheung and $\mathrm{Ng}$ (1992) also observed the price fluctuation of common stock price of the company is driven by the respective size of common stock with a negative direction. Apart from these, British researcher, Hussainey et al., (2011), Malaysian researcher, Hashemijoo et al., (2012), Haque et al., (2019) who studied the similar topic in the market of Bangladesh, as well as Vietnamese researchers, Anh and Nhi (2016) together with Nguyen et al., (2020) reached the same conclusion in terms of the negative correlation that the size of enterprise has on the price fluctuation of common stock in the designated financial markets that they studied in, which are consistent with previous studies. In contrast, Nishat and Irfan (2004), Sadiq et al., (2013) and Al-Shawawreh (2014) showed that the size of enterprise is associated with the price volatilization of respective common stock in a negative way in the stock market of Pakistan, and Jordan respectively. Furthermore, Both Iranian researchers, Lashgari and Ahmadi (2014) raised out that no association is significant enough to be identified among these two observations.

2.3.3 Impact or Influence the Ratio of Leverage may have on the Price Fluctuation of Respective Common Stock

Black (1976) became the first to take priority to conduct assessment and pointed out the ratio of leverage is correlated to the price fluctuation of respective common stock, Later in 1982 and 1989, both researchers, Christie (1982) and Schwert (1989) concluded the outcomes to be in alignment with said first study. Such assessment and examination had rapidly expanded to developed and developing countries including both Australian researchers, Allen and Rachim (1996), two researchers of Pakistan, Nishat and Irfan (2004) as well as British researcher, Hussainey et al., (2011) concluded the same outcomes with the previous hypothesis. In recent years, the findings from two Vietnamese researchers, Anh and Nhi (2016) and Nguyen et al., (2020) are also in alignment with the previous studies. However, with the statical outcomes from Iranian researchers Lashgari and Ahmadi (2014), it is emphasized with the conclusion that no particular correlation is identified between the ratio of leverage and the price volatilization of respective common stock.

2.3.4 Impact or Influence the Volatilization of Earnings may have on the Price Fluctuation of Respective Common Stock

Apart from the above-mentioned statistical outcomes, American research, Baskin (1989) also raised out the price volatilization of respective common stock would be driven by the volatilization of earnings which is quite understandable. Later in 1996, both Australian researchers, Allen and Rachim (1996) agreed with that as well. Additionally, in developing country, Vietnamese researcher, Nguyen et al., (2020) conducted his similar study and also raised out the same thoughts. However, Sadiq et al., (2013) in Pakistan and Lashgari and Ahmadi (2014) in Iran found the earnings volatility does not have effects on the volatility of common stock price. 
2.3.5 Impact or Influence the Growth Ratio of Assets may have on the Price Fluctuation of Respective Common Stock

The price fluctuation of the company's common stock would not be driven by the company's growth ratio of assets, was firstly raised out by both Australian researchers, Allen and Rachim (1996), even since then, in developed country, British researcher, Hussainey et al., (2011) also confirmed and obtained the consistent results, as well as in developing country, two Malaysian researchers, Zakaria et al., (2012) and Sew et al., (2015) revealed their studied and showed there is no significant relationship exists in between. In the contrary, Sadiq et al., (2013) revealed that growth ratio of assets of the company is significant associated with the price volatilization of respective common stock with the positive direction, with 35 companies which are not financial institutions and go public on KSE of Pakistan to be the sample and a length of 11 years from 2001 to 2011. Both Iranian researchers, Lashgari and Ahmadi (2014) as well as Malaysian research, Zainudin et al., (2018) raised out the same statistical outcomes with all these previous studies. Only Profilet and Bacon (2013) in United States found a significant negative relationship between these two variables. Nguyen et al., (2020) in Vietnam also found the growth of asset is significantly correlated with the volatility of common stock price.

\subsection{Conclusion of the Chapter}

Concerning whether the policy or regulation of the company towards the payment of dividend would volatilize or fluctuates the price of respective common stock, among all researches conducted similar studies in the past, they have no yet reached to a mutual agreement. In addition, the statistical outcomes of these studies showed the relationship between other control variables are diverse, with some indicating positive while some showing negative. The companies across varied geographical locations and sectors are studied but the range of the types of the companies are universal. There is not particular study conducted on the companies especially in the stock market of Hong Kong. 


\section{CHAPTER III: DESIGN AND RESPECTIVE METHODOLOGY OF THE STUDY}

\subsection{Research Design and Respective Methodology}

This dissertation identifies what the influence or impact that dividend policy would have on the price fluctuation of respective common stock price in Stock Exchange of Hong Kong and the respective research philosophy, methodology and design will be discussed in this Chapter.

\subsection{Research Philosophy and Methodological Approach}

Considering the research is conducted by objective observation on listed companies in the stock market of Hong Kong and measurement of variable to conclude the results, it is considered to be positivism paradigm for the research philosophy of this study with quantitative approach to be employed as the research methodology.

A deductive approach is chosen to this study since the analysis in later chapters is based on quantitative data to observe how dividend policy influences on the volatility of common stock price which is more structured compared to indicative approach that focused on the understanding and clarification of humanconstructed meanings associated with particular events.

\subsection{Research Design}

To identify the possible influence of impact of dividend policy on the price fluctuation of respective common stock or whether it will volatilize the price of common stock by respective dividend policy. As such, it is considered appropriate to perform analysis by taking the dependent variable, the price volatility of corresponding common stock, independent variables representing the company's policy, strategy or plan towards dividend, as well as control variables that are considered to be applicable in this study with timeseries data of these variables. Panel data analysis is considered appropriate to adopt in this research since all data involved are on past-even basis and measurements over certain long period of time are involved in Panel data analysis as well as longitudinal unit of analysis.

To be consistent with the analytical framework of Baskin (1989), the degree of price fluctuation representing how volatilized the price of designated common stock is adopted as the dependent variable while two major independent variables, namely the yield and the pay-out ratio of dividend are representing as the proxies of dividend policy in this hypothesis. In addition, several control variables including enterprise size, leverage, the volatility of earnings and asset growth are adopted for analysis of correlation to see how they would volatilize the price of respective common stock.

To include sufficient information for analysis, chosen sample data covered a relatively long period for 20 years from 2001 to 2020 and totaling 354 enterprise which are not financial institutions go public in the Stock Exchange of Hong Kong were chosen for analysis. 
Correlation Analysis is performance to preliminary observe the degrees of correlation between variables in this research. Consequently, it becomes necessary to identify in case of collinearity, as well as any mutual influence may possibly exist amount adopted variables, as such, the test of Multicollinearity is considered appropriate to be performed. If the VIF (variance expansion factor) value of each variable greater than 10 , meaning multicollinearity exists, and vice versa. Multi-regression analysis can be performed afterwards.

Either the model or fixed or random effects is expected to adopted for further experiment. Therefore, F-test and Hausman test are performed before panel data regression analysis, to provide judgement on the proper selection within these two statical tools. Rather than choosing the model of random effects, considering the results on model testing and by the comparison to ordinary least squares (OLS), to employ the model of fixed effects for analysis will be fitting for the later statical approach.

\subsection{Variables Applied for the Measurement}

Following the study blueprint of the primary study of Baskin (1989), as well as the follower research, Allen and Rachim (1996), both of them adopted almost the same variables to be in analysis but the calculation methods are adjusted and shown in the following parts. The variables used to measure in this study comprises three categories of variables including dependent, independent and control variables totaling 7 variables for analysis. These used variables will be descripted in detail and explained their importance to identify any influence that the company's regulation or policy regarding dividend payment to its shareholders may have on the price fluctuation of respective stock within the capital market of Hong Kong, so that to ensure the robustness of research analysis.

\subsubsection{Dependent Variable Applied to the Study}

Being the main reference for other variables, the price volatilization of common stock price is adopted to be the dependent variable for the identification of possible correlation may exist among them.

\subsubsection{The Price Volatilization of Common Stock}

The price volatilization of common stock (PVOL) is calculated by using the extreme value within the fiscal year of the common stock price. This method used highest and lowest common stock price is considered reflecting a more complete state of volatility compared to using the annual opening and closing prices since the fluctuations within the period may be omitted.

Specifically, the method is to subtract the lowest common stock price from highest common stock price each year, and subsequently divide by the average of the sum of yearly highest closing price and lowest closing price of stock. Finally, the result will then be obtained after being squared. Respective formular is as follow:

$$
\mathrm{PVOL}=\left[(\mathrm{Hi}-\mathrm{Li}) / \frac{H i+L i}{2}\right]^{2}
$$


Where:

PVOL means the closed price volatilization of common stock.

$\mathrm{H}_{\mathrm{i}}$ means the closed price that is recorded the highest of i common stock in that year.

$\mathrm{L}_{\mathrm{i}}$ means the closed price that is recorded the lowest of $\mathrm{i}$ common stock in that year.

\subsubsection{Independent Variables}

\subsubsection{The Yield of Dividend}

The yield of dividend (DY) is referred the percentage of dividend payment accounted for the annual earnings of the enterprise. More specifically, it would be taking the number of annual dividends of ordinary shareholders as the numerator and then divided by the respective market value of ordinary shares with the point of time assumed to be at the first trading day of the year. In this research, the method used to determine the yield of dividend is taking dividend per common share and then divided by the price of common stock that assumed to be the first trading day of the year. The formula of the yield of dividend is as:

$$
D Y_{i t}=D P S_{i t} / P P S_{i t}
$$

Where:

$\mathrm{DY}_{\text {it }}$ means company i's yield of dividend in t year.

DPS $_{\text {it }}$ means company i's dividend per common share in $t$ year.

PPS $_{\text {it }}$ means company i's price per common stock at the beginning of $t$ year.

\subsubsection{The Ratio of Pay-out Ratio Dividend}

The ratio of pay-out of dividend (DPR) is another main independent variable studied in this research and it refers to the percentage of dividends that the company would pay from its earnings to its shareholders yearly. In detail, it will be taking the percentage of dividend compared to its earnings, or cash dividend paid to ordinary shareholders, and subsequently divided by company's annual net profit after tax. In this study, the pay-out ratio of dividend is likewise formulated as:

$$
D P R_{i t}=D P S_{i t} / E P S_{i t}
$$

Where:

$\mathrm{DPR}_{\mathrm{it}}$ means company i's pay-out ratio of dividend in t year.

DPS $_{\text {it }}$ means company i's dividend per share in t year.

EPS $_{\text {it }}$ means company i's earnings per share in $t$ year. 


\subsubsection{Control Variables}

For strengthen the correlation results of correlation among selected variables, there are control variables totaling four variables including enterprise size, leverage, the volatility of earnings and asset grow rate are employed in the study.

\subsubsection{The Size of Enterprise}

Generally, larger size of companies provide stability in terms of operational and financial status. In this study, it is simply to take the number of total assets by the year-end to denote the size of designated enterprise (SIZE). However, for better statistical assessment as well as presentation, the number of total assets is adjusted with the logarithm prior to the input in statical tools performed in later part.

\subsubsection{The Ratio of Leverage}

Leverage (LEVE) is referring to the amount of debt a company has and it indicates how much a company is using to finance its assets. Leverage generally includes all other borrowings apart from the enterprise's own source of funds, however, longer term portion of debt tends to be more stable and without significant fluctuation on the company's financials compared to shorter term portion of debt. Thus, we took the longterm portion of debt to be the numerator and the amount of total assets by the end of the year to be the denominator, representing the ration of leverage with formular stated as follow:

Where:

$$
L E V E_{i t}=L T D_{i t} / T A_{i t}
$$

$\mathrm{LEVE}_{\mathrm{it}}$ means the leverage ratio of company i's in t year.

LTD $_{\text {it }}$ means the long-term portion of debt by the end of fiscal year of company $i$ in $t$ year.

$\mathrm{TA}_{\mathrm{it}}$ means the value of total assets by the end of the fiscal year of company $\mathrm{i}$ in $t$ year.

\subsubsection{The Volatilization of Earnings}

The volatilization of earnings (EV) is to calculate the volatility in terms of profitability. This could be simply obtained by taking the company's earnings before interest and tax (EBIT) by the end of the fiscal year as numerator, and the subsequently divided by the denominator, namely the value of total assets by the end of fiscal year. The respective standard deviation could be thereby obtained with the said ratio after calculation. The volatility of earnings is formulated as: 


$$
E V_{i t}=\sqrt{\frac{\left(R_{i t}-\bar{R}_{l}\right)^{2}}{n-1}}
$$

Where:

$\mathrm{EV}_{\text {it }}$ means company i's volatilization of earnings in $\mathrm{t}$ year.

$\mathrm{R}_{\mathrm{it}}$ means the value of earnings before interest and tax (EBIT) to the value of total assets by the end of fiscal year of company $\mathrm{i}$ in $\mathrm{t}$ year.

$\overline{\mathrm{R}_{1}}$ means the average value of $\mathrm{R}_{\mathrm{it}}$ of company $\mathrm{i}$ during the study period.

\subsubsection{The Growth Ratio of Assets}

The growth ratio of assets (GRO) in this research is referring to the growth ratio in assets, with the numerator to be discrepancy between the value of total assets on last trading day of the fiscal year and the value of total assets on the first trading day of the fiscal year of the same company, and subsequently taking the value of total assets on the first trading day of the fiscal year to be the denominator for calculation. The rate of asset growth is formulated as:

Where:

$$
G R O_{i t}=\frac{A S S E T_{i t}-A S S E T_{i t-1}}{A S S E T_{i t-1}}
$$

$\mathrm{GRO}_{\text {it }}$ means company i's rate of asset growth in $t$ year.

ASSET $_{\text {it }}$ means the value of total assets of company $i$ on the last trading day in t year.

ASSET $_{\mathrm{it}-1}$ means the value of total assets of company $i$ on the first trading day of $t$ year. 
The measurement of variables and relevant studies are summarized in Table 3.1 below:

Table 3.1: Summary of Measurement of Adopted Variable in Research

\begin{tabular}{|c|c|c|}
\hline Variable Name & Acronyms & Measurement \\
\hline \multicolumn{3}{|l|}{ Dependent variable } \\
\hline $\begin{array}{l}\text { The price } \\
\text { volatilization of } \\
\text { common stock }\end{array}$ & PVOL & $\begin{array}{l}\text { To subtract the lowest common stock price from highest common stock price each year, and } \\
\text { subsequently divide by the average of the sum of yearly highest closing price and lowest closing } \\
\text { price of stock. Finally, the result will then be obtained after being squared. }\end{array}$ \\
\hline \multicolumn{3}{|c|}{ Corresponding Independent variables } \\
\hline The yield of dividend & DY & $\begin{array}{l}\text { Taking dividend per common share and then divided by the price of common stock that assumed to } \\
\text { be the first trading day of the year. }\end{array}$ \\
\hline $\begin{array}{l}\text { The pay-out ratio of } \\
\text { dividend }\end{array}$ & DPR & $\begin{array}{l}\text { Taking the percentage of dividend compared to its earnings, or cash dividend paid to ordinary } \\
\text { shareholders, and subsequently divided by company's annual net profit after tax }\end{array}$ \\
\hline \multicolumn{3}{|c|}{ Corresponding Control variables } \\
\hline The size of enterprise & SIZE & $\begin{array}{l}\text { The value of total assets by the end of fiscal year after the mathematical processing method of } \\
\text { logarithm, to denote the respective size of enterprise. }\end{array}$ \\
\hline The ratio of leverage & LEVE & $\begin{array}{l}\text { Taking the value of long-term portion of debt as numerator and the value of total assets as } \\
\text { denominator with both value at the end of the fiscal year of the company. }\end{array}$ \\
\hline $\begin{array}{l}\text { The volatilization of } \\
\text { Earnings }\end{array}$ & EV & $\begin{array}{l}\text { Taking the standard deviation of the ratio which is calculated by taking earnings before interest and } \\
\text { tax by the end of the fiscal year as numerator and the value of total assets by the end of the fiscal } \\
\text { year as denominator. }\end{array}$ \\
\hline $\begin{array}{l}\text { The Growth Ratio of } \\
\text { Assets }\end{array}$ & GRO & $\begin{array}{l}\text { Taking the variance between the value of total assets on the last trading day of the fiscal year and the } \\
\text { first trading day of the fiscal year. }\end{array}$ \\
\hline
\end{tabular}

Source: Author's Compilations (2021) 


\subsection{Sampling and Sampling Size}

The variables to be used in analysis are obtained from the chosen companies go public in the Stock Exchange in Hong Kong which is the largest bourse worldwide in terms of market capitalization.

There are 2,538 companies listed on HKEX as of the fiscal year end of 2020. In consideration of sufficient length of the secondary data, the data set is designed to obtain from the companies listing for at least 20 years from 2001 to 2020. After consolidation, there are 387 companies listed on HKEX possess historical financial data for 20 years are available for study. Among these companies, 354 companies are identified to be sufficiently and significantly reflected the market conditions of Hong Kong stock market, excluding financial institutions due to dissimilar format on account reporting standard and companies without longterm liabilities and missing essential data significant. Total of 6,983 effective sample points is retrieved from the data stream of WIND and the information are sourced from the audited financial statements mandatorily published on HKEX on a regular basis. In addition, these selected companies for study are across various sectors and different industries, as well as featured with different scale, financial situation and profitability.

\subsubsection{Data Collection Methods and Procedures}

In this study, the sources of data are outputted from the data stream in WIND, the leading financial information service provider in China, providing accurate information to financial professionals. Prior to the examine the hypothesis, the time-series of data set of chosen listed companies in HKEX are required to obtain, and it consists of dependent variable referring to the volatility of common stock price, independent variables referring to the yield and the ratio of pay-out of dividend denoting the policy or regulation of the company regarding dividend payment to its shareholders and control variables referring to the size of enterprise, the ratio of leverage, the volatility of earnings and the growth of asset. All these data are publicly accessible on the audited financial statements regularly released on HKEX exchange due to mandatory submission complying with respective laws and regulations. Following the previous studies, similarly, data are secondary data available from the local stock exchange where the research conducted at. Details of data extracted are presented in Appendix A.

\subsection{Statistical Methods for Data Analysis}

In order to provide a thorough and robust data analysis, a popular statistical software package for conducting data science, namely STATA (version 14) is adopted for mathematical processing to obtain the statical output for further analysis.

\subsubsection{The Respective Description of Statistics}

The respective description of statistics will be stated in Chapter four with the summary of necessary components for analysis including several commonly seen statistical terms including the value of mean, maximum and minimum, along with the respective mathematical standard deviation, showing the central tendency that help understanding the elements and features of all applied variables of the sample data used. 


\subsubsection{The Analysis Based on Correlation}

Spearman correlation was chosen to conduct analysis and generate the value of correlation coefficient for the determination of the correlation between all variables which are totaling in 7 . Such analysis on statical correlation provided a significant reference in term of the directional significance among adopted variables. Prior to the conduct of regression analysis, it is utmost necessary to firstly identify whether the multicollinearity occurs between applied variables, as such, a multicollinearity test is also conducted to check whether the value of VIF is greater or lesser than 10.

\subsubsection{The Analysis on Regression}

For the sake of investigation on the possible influence that the company's policy may have on the price fluctuation of respective common stock effectively, the regression analysis is employed in this research to examine any relationship with casual effect exists between variables including dependent, independent and control variables. Panel data analysis is to employed to examine the hypothesis raised out in previous chapter concerning sample data chosen in this study are time-series data and estimation approaches consists of the statistical model of the effects meaning in both format of fixed and random.

\subsection{Research Model Specification and Estimations}

\subsubsection{Research Model Specification}

The model is for the investigation of the any possible influence that the company's policy and regulation regarding dividend payment which is proxied with the yield and the ratio of pay-out of dividend would have on the price fluctuation of corresponding common stock. Other control variables will also be examined. The empirical models are setup follows below:

$$
P V O L_{i}=\alpha 0+\alpha 1 D Y_{i}+\alpha 2 D P R_{i}+\alpha 3 S I Z E_{i}+\alpha 4 L E V_{i}+\alpha 5 E V_{i}+\alpha 6 G R O_{i}+\beta
$$

Where:

PVOL means the price volatilization of common stock and being adopted as the dependent variable.

DY means the yield of dividend and being adopted as the independent variable.

DPR means the ratio of pay-out of dividend and being adopted as the independent variable.

SIZE means the size of enterprise and being adopted as the control variable.

LEVE means the ratio of leverage and being adopted as the control variable.

EV means the volatilization of earnings and being adopted as the control variable.

Gro means the growth ratio of company's assets and being adopted as the control variable.

$\alpha 0$ to $\alpha 6$ are coefficients, while $\beta$ is the stochastic disturbance

3.7.2 Estimation Approaches

In this study, the technique of panel data analysis is employed in view of the results provide better estimates with lesser multicollinearity over cross-section as well as time-series set of data. Adopted approaches for

The impact of the dividend policy on the price volatilization of common stock

- Evidence from the stock market of Hong Kong 
estimation comprise of the statistical model of the effects in the form of fixed and random during mathematical analysis.

\subsubsection{Diagnostic Test}

Diagnostic test is necessary to perform in this study on the selection of fixed effects or random effects model, and thereby F-test and Hausman test are employed to judge which of these two regression models to use. The value of F-statistics and probability value from both mentioned tests will provide references on the model to be rejected or accepted.

\subsection{Ethical Issues in Research}

The chosen sample data are secondary data publicly accessible on Hong Kong Stock Exchange (HKEX). The information of all used variable is available on their annual or semi-annual reports that are mandatory to published on HKEX regularly, and thus, there is no approval or consent to be obtained prior to the use of data concerning ethical issue.

\subsection{Limitations of Study}

There are over 2,500 listed companies recorded at the end of Nov 2020, up from 1,200 in 2008 in HKEX of Hong Kong.

In spite of the sample data of this study consists of 354 listed companies, the simple data is still considered relatively small comparing to the whole. In addition, it excluded financial institutions as well as companies with no liability and missing data significantly. The study may not sufficiently represent the market conditions in Hong Kong stock market.

Moreover, the study is carried out particularly based on Hong Kong stock market, hence it could not extend the understanding to other stock market other than the stock market in Hong Kong. 


\section{CHAPTER IV: ANALYSIS OF DATA, RESPECTIVE RESULTS AND DISCUSSION}

\subsection{Analysis and assessment of Data}

The statistical tools are employed for assessing and analyzing the chosen sample set of data to generate the research outcomes throughout the whole chapter. Several parts including descriptive statistics, correlation analysis and regression are included in this chapter to provide the insights of the statistical outcomes.

\subsection{Treatment of Outliers}

In this study, all continuous variables were tailed up and down by $1 \%$ to deal with the problem of outliers to prevent the presence of outliers caused violation in the Panel data regression analysis.

\subsection{Descriptive Statistics of Sample Data}

A profile of 354 companies listed in HKEX are observed and total amounts of 6,983 effective sample data are involved in this study as shown in Table 4.1.

The volatility of common stock price (PVOL) has the numbers for maximum and minimum of 3.058 $(305.80 \%)$ and $0.0257(2.57 \%)$ respectively, along with the mean and the corresponding standard deviation to be $0.887(88.70 \%)$ and $0.721(72.10 \%)$ respectively, implying the common stock price has significant fluctuation between the companies used in this study.

The yield of dividend (DY) and the pay-out ratio of dividend (DPR) are employed to be the proxies of dividend policy. With the figures showed in Table 4.1, the yield of dividend (DY) has a number of minimum of $0(0.00 \%)$ meaning that partial companies are not paying dividend regularly, the corresponding number of maximum and the mean are $0.390(39.00 \%)$ and $0.0471(4.71 \%)$ respectively, suggested the yield of dividend between companies in this research are varied but the amount of dividend paid to common shareholder are fairly good. Meanwhile, the pay-out ratio of dividend (DPR) has a number for minimum of $-1(-100.00 \%)$, a number for maximum of 2.59 (259.00\%) and a number for mean of $0.326(32.6 \%)$. These results indicated some companies paid dividends more than their earnings with sourced from other funding channels instead of earnings.

The enterprise size (SIZE) of chosen companies listed on HKEX concluded the numbers of maximum, mean and minimum are 28.65, 21.29 and 16.52 respectively, indicating corresponding scale of these companies is relatively large, mainly due to the chosen companies have been listed for more than 20 years, providing them enough time to growth and to meet the size requirement of listing.

The leverage (LEV) is referred to the long-term debt ratio. The results showed the numbers for maximum, average and minimum are $0.445(44.50 \%), 0.126(12.60 \%)$ and $0(0.00 \%)$ respectively, and the value of average number is relatively close to the standard deviation of 0.127 (12.7\%), implying the sample companies in this research generally financed with comparatively low borrowing and some companies do not even maintain any long-term debt. 
The volatility of Earnings (EV) with the numbers for maximum and minimum of $0.179(17.90 \%)$ and 0 $(0.00 \%)$ respectively, along with the number for mean standard deviation stayed low at $0.0279(2.79 \%)$ and $0.0385(3.85 \%)$ respectively, showing the volatility of earnings of sample companies are relatively low and some companies do not have change in earnings.

Asset Growth (GRO) with a minimum number of -0.620 (-62.00\%), a maximum number of $1.123(123.30 \%)$ and an average number of $0.106(10.60 \%)$, indicating the chosen companies listed on HKEX have stable pace of development.

Table 4.1: Descriptive Statistics

\begin{tabular}{lcccccc}
\hline Variables & $\mathbf{N}$ & Mean & Std. Dev. & Min. & P50 & Max. \\
\hline PVOL & 6983 & 0.887 & 0.721 & 0.0257 & 0.682 & 3.058 \\
DY & 6983 & 0.0471 & 0.0840 & 0 & 0.0155 & 0.390 \\
DPR & 6983 & 0.326 & 0.567 & -1 & 0.168 & 2.590 \\
SIZE & 6983 & 21.29 & 1.799 & 16.52 & 21.05 & 28.65 \\
LEV & 6983 & 0.126 & 0.127 & 0 & 0.0816 & 0.445 \\
EV & 6983 & 0.0279 & 0.0385 & 0 & 0.0139 & 0.179 \\
GRO & 6983 & 0.106 & 0.285 & -0.620 & 0.0603 & 1.123 \\
\hline
\end{tabular}

Source: Researchers' Computation (Stata 14) 2021

Note: Std. Dev. = Standard Deviation

\subsection{Correlation Analysis of Sample Data}

From the Table 4.2., apparently, the obvious association and correlation among designated variables are shown on it. It is apparently seen that most of the variables are significantly related to others and the results are a mixture of positive and negative correlation coefficients listed on the table.

The results of correlation analysis indicated the yield of dividend and the volatility of common stock price are insignificant correlated which is required to be tested by regression analysis in the following part, while the pay-out ratio of dividend is negatively associated to the volatility of common stock price at $1 \%$ level of significance, implying the higher the pay-out ratio of dividend leads to the lower price fluctuation of common stock based on the chosen sample data.

It is interesting to see the size of enterprise size has a comparatively high association but in a negative way to the price fluctuation of common stock at $1 \%$ significant level, which led to the conclusion that the company with larger size means it would have lower price fluctuation of its common stock. Likewise, leverage is significantly negatively correlated with the volatility of common stock price at the $1 \%$ significance level, indicating that the higher the leverage, the lower the volatility of common stock price.

The impact of the dividend policy on the price volatilization of common stock 
In addition, the volatility of earnings is found be also significantly associated to the price fluctuation of the respective common stock price but in the positive way with significance level at $1 \%$, while assets growth and the price fluctuation of common stock are significantly negatively correlated at the $1 \%$ significance level.

Table 4.2: Spearman Correlation

\begin{tabular}{|c|c|c|c|c|c|c|c|}
\hline & PVOL & $\overline{D Y}$ & $\overline{\text { DPR }}$ & $\overline{\text { SIZE }}$ & LEV & $\mathbf{E V}$ & GRO \\
\hline PVOL & 1 & & & & & & \\
\hline DY & -0.0120 & 1 & & & & & \\
\hline DPR & $-0.200 * * *$ & $0.284 * * *$ & 1 & & & & \\
\hline SIZE & $-0.533 * * *$ & $0.042 * * *$ & $0.265^{* * * *}$ & 1 & & & \\
\hline LEV & $-0.097 * * *$ & $-0.104 * * * *$ & $-0.027 * *$ & $0.237 * * *$ & 1 & & \\
\hline EV & $0.064 * * *$ & -0.00500 & $-0.121 * * *$ & $-0.182 * * * *$ & $0.082 * * * *$ & 1 & \\
\hline GRO & $-0.079 * * * *$ & 0.00800 & -0.0130 & $0.165 * * *$ & $0.137 * * *$ & $-0.064 * * *$ & 1 \\
\hline
\end{tabular}

Dependent, Independent and Control Variables in the above table are defined as follows: The Volatility of Common Stock Price (PVOL), The Yield of Dividend (DY), The Pay-out Ratio of Dividend (DPR), Enterprise size (SIZE), Leverage (LEV), The Volatility of Earnings (EV) and Asset growth (GRO).

\subsection{Multicollinearity Test}

According to the table of Spearman Correlation, apparently, the correlation coefficients revealed all dependent, independent and control variables are somehow linked and associated with some others. Therefore, the study conducts a multicollinearity test on the variables to avoid the mutual influence between the variables and the collinearity. The results show in Table 4.3 with the VIF value of each variable tabulated. It is observed that none of these VIF values of variables is lesser than 10, meaning there is absence of multicollinearity between these variables. As such, the multiple regression analysis can be employed to further test the relationship between these variables. 
Table 4.3: Multicollinearity Test

\begin{tabular}{ccc}
\hline Variables & VIF & 1/VIF \\
\hline SIZE & 1.21 & 0.8256 \\
DPR & 1.19 & 0.8438 \\
LEV & 1.11 & 0.9018 \\
DY & 1.1 & 0.9078 \\
EV & 1.06 & 0.9423 \\
GROWTH & 1.05 & 0.9565 \\
Mean VIF & 1.12 & \\
\hline & Note: VIF = Variance Inflation Factor
\end{tabular}

\subsection{Panel Data Regression Analysis}

To perform panel data regression analysis during data analysis or assessment, it is very often to use the model of fixed effects and random effects, to conclude the correlation that may exist among adopted variables, namely in this study, are the yield and the ratio of pay-out of dividend, the size of enterprise, leverage, the volatility of earnings, growth and the price volatility of respective common stock. Signal “ * ", “**” and " ***" represents level of significant at the value of $10 \%, 5 \%$ and $1 \%$ respectively.

\subsubsection{F-test and Hausman Test}

F-test and Hausman test are performed before panel data regression analysis, to provide judgement on proper statistical tool of regression Analysis, meaning the model of random or fixed effects should be adopted for further testing properly.

Table 4.4 shows the value of F-statistics and the corresponding Probability value are 25.93 and 0.0000 respectively. It clearly rejects the null hypothesis that there is no individual difference and suggests that employing fixed effects model (FEM) for analysis by comparison to ordinary least squares (OLS).

The statical outcome of Hausman's test is 30.33 and the number of corresponding probability is 0.0000 . As such, to employ the model of fixed effects is considered the proper statical measure in the analysis of regression since the probability value of Hausman test is below 0.01 , implying the null hypothesis that the estimated values is significantly rejected at the significance level of $1 \%$. 
Table 4.4: The statical outcomes of Hausman Test and F-test

\begin{tabular}{lcc}
\hline Model & F-test & Hausman Test \\
\hline Statistics & 25.93 & 30.33 \\
\hline Probability Value (PV) & 0.0000 & 0.0000 \\
\hline
\end{tabular}

\subsubsection{Regression Analysis}

The presentation of the respective statical outcomes is tabulated in Table 4.5, where the figures from the model of fixed effects and random effects are in column 1 and column 2 correspondingly. As mentioned earlier, it is the properly to use the model of fixed effects concerning the statical outcomes supported such measurement.

After the statical outcomes outputted from the use of the model of fixed effects, apparently, the level of significance is valued at $5 \%$ for the yield of dividend with the negative coefficient concluded, explaining the increment in the yield of dividend can significantly reduce the volatility of common stock price. Its coefficient is -0.155 , indicating the increase of 1 unit in the yield of dividend reduces the price fluctuation of common stock by 0.155 unit. This shows that the yield of dividend and the price fluctuation of common stock are obviously negatively associated with each other which supports Hypothesis (H1a), that is, the increment in the yield of dividend can effectively suppress the price fluctuation of respective common stock. Therefore, the yield of dividend could be considered to be an indicator from the perspective of the cost and income of investors and it has a strong correlation with investors' investment decisions and investment behaviors. The increase or decrease in the yield of dividend has significant impacts on the investment decisions of investors and it will also affect the stability of listed companies' common stock prices to a greater extent in Hong Kong stock market.

Level of significance at $5 \%$ is obtained for the pay-out ratio of dividend with the negative coefficient concluded after statical output, explaining that an increase in the pay-out ratio of dividend can significantly reduce the volatility of common stock price. This supports Hypothesis (H2a). Its coefficient is -0.029, indicating that the pay-out ratio of dividend increases by 1 unit, the respective price of common stock fluctuates and decreases by 0.029 unit correspondingly. As such, the ratio of pay-out of dividend is apparently associated to the price fluctuation of respective common stock in the negative way, that is, any increase in the ratio of pay-out of dividend can effectively suppress the fluctuation of common stock price.

The pay-out ratio of dividend is a vital part of dividend policy and represents the distribution of dividends. The distribution of cash dividends has higher requirements for the financial competency and profitability of listed companies. High cash dividends often indicate a better company's financial status. Therefore, listed companies that distribute higher cash dividends are more likely to attract investors to invest and hold for a longer period of time, and their common stock prices are relatively more stable. 
From the outcomes of other control variables, the enterprise size (SIZE) is shown at $1 \%$ significance level while the coefficient is negative, supporting Hypothesis (H3a) and indicating that larger size of enterprise comes with lower price fluctuation of the respective common stock which is mainly attributable to the fact that larger companies receive more attention from investors, and investors can obtain more effective information from the capital market, and thereby reducing the speculative behavior in the capital market and stabilizing the common stock price of listed companies.

The volatility of Earnings (EV) is shown at $1 \%$ significance level while the coefficient is positive, supporting Hypothesis (H5a) with the indication that the greater volatility of earnings lead to lower price fluctuation of the company's common stock, mainly attributable to the greater the volatility of the company's earnings, the smaller the proportion of dividends they will use as dividend payments due to uncertainty on profitability. As such, dividend payments can be a signal implying the company's business profitability. When dividend payments are reduced, market speculation will increase, resulting in unusual volatilized price of respective common stock.

In contrast, there no association is identified significantly between two control variables, namely the leverage, the enterprise's growth rate of Asset growth and the price fluctuation of respective common stock. These two variables are considered important fundamental factors to common stock price as companies with good fundamentals are likely to attract investors to hold stocks for a longer time, which will help stabilizing the volatility of common stock price. Nevertheless, these two variables in this study are found not significant with the volatility of common stock price, which may be due to the serious speculative behavior and herd effect of investors in the Hong Kong stock market, led to lack of attention to fundamental information when investing in stocks, and thereby the company's leverage and asset growth rate mostly do not affect the price fluctuation of respective common stock.

To summarize, the yield and the pay-out ratio of dividend can reduce the price fluctuation of corresponding common stock, mainly attributable to enterprise's decision on distribution of dividend will affect the composition of investors and their investment behavior. Investors attracted by listed companies with high cash dividends are often long-term investors pursuing cash dividend returns. Such investors are willing to hold stocks of such companies for a long time and usually do not conduct frequent buying and selling transactions, which will help maintaining the stability of the company's common stock price. 
Table 4.5: Regression Analysis of Fixed Effects Model and Random Effects Model

\begin{tabular}{|c|c|c|}
\hline Variables & $\begin{array}{c}(1) \\
\text { FEM } \\
\text { PVOL } \\
\end{array}$ & $\begin{array}{c}(2) \\
\text { REM } \\
\text { PVOL } \\
\end{array}$ \\
\hline DY & $\begin{array}{c}-\mathbf{0 . 1 5 5} * * \\
(-2.096)\end{array}$ & $\begin{array}{l}\mathbf{- 0 . 1 3 5} * \\
(-1.842)\end{array}$ \\
\hline DPR & $\begin{array}{c}-\mathbf{0 . 0 2 9} * * \\
(-2.559)\end{array}$ & $\begin{array}{c}\mathbf{- 0 . 0 3 3} * * * \\
(-2.931)\end{array}$ \\
\hline SIZE & $\begin{array}{c}\mathbf{- 0 . 2 1 2} * * * * \\
(-36.273)\end{array}$ & $\begin{array}{c}\mathbf{- 0 . 2 1 0} * * * * \\
(-38.173)\end{array}$ \\
\hline LEV & $\begin{array}{c}0.034 \\
(0.656)\end{array}$ & $\begin{array}{c}0.045 \\
(0.886)\end{array}$ \\
\hline EV & $\begin{array}{c}\mathbf{0 . 5 6 7} * * * * \\
(2.990)\end{array}$ & $\begin{array}{c}\text { 0.472*** } \\
(2.545)\end{array}$ \\
\hline GRO & $\begin{array}{c}-0.028 \\
(-1.574)\end{array}$ & $\begin{array}{c}-0.028 \\
(-1.558)\end{array}$ \\
\hline Constant & $\begin{array}{c}\mathbf{5 . 1 5 3}^{* * *} * \\
(40.359)\end{array}$ & $\begin{array}{c}\mathbf{5 . 1 1 5}^{* * *} \\
(41.769)\end{array}$ \\
\hline $\begin{array}{l}\text { Observations } \\
\text { R-squared } \\
\text { Number of id }\end{array}$ & $\begin{array}{c}6,983 \\
0.364 \\
354\end{array}$ & $\begin{array}{c}6,983 \\
0.363 \\
354\end{array}$ \\
\hline
\end{tabular}

t-statistics in parentheses

Note: Significant levels “****, “**” and “*” are referred to $p<0.01, \mathrm{p}<0.05$ and $* \mathrm{p}<0.1$ respectively

\subsubsection{Adjusted Analysis of Regression}

Concerning the dividend policy from the current period will affect the price fluctuation of respective common stock in the next period, the explanatory variables are replaced to be the price fluctuation of corresponding common stock in next period, we therefor adjusted accordingly in the model of fixed effects and random effect employed in the analysis of regression with results stated as follows: 
Table 4.6: Adjusted Results of Regression Analysis

\begin{tabular}{|c|c|c|}
\hline Variables & $\begin{array}{c}\text { (1) } \\
\text { FE } \\
\text { FVOL }\end{array}$ & $\begin{array}{c}(2) \\
\text { RE } \\
\text { FVOL }\end{array}$ \\
\hline DY & $\begin{array}{c}\mathbf{- 0 . 5 9 8} * * * \\
(-8.091)\end{array}$ & $\begin{array}{c}\mathbf{- 0 . 5 5 6} * * * \\
(-7.608)\end{array}$ \\
\hline DPR & $\begin{array}{c}-\mathbf{0 . 0 2 6} * * \\
(-2.205)\end{array}$ & $\begin{array}{c}-\mathbf{0 . 0 3 2} * * * \\
(-2.741)\end{array}$ \\
\hline SIZE & $\begin{array}{c}-\mathbf{0 . 1 9 5} * * * * \\
(-32.817)\end{array}$ & $\begin{array}{c}-\mathbf{0 . 1 9 6} * * * \\
(-35.097)\end{array}$ \\
\hline LEV & $\begin{array}{c}\mathbf{0 . 1 1 6} * * \\
(2.236)\end{array}$ & $\begin{array}{c}\mathbf{0 . 1 2 2} * * \\
(2.384)\end{array}$ \\
\hline EV & $\begin{array}{c}\mathbf{0 . 6 0 0} * * * * \\
(3.029)\end{array}$ & $\begin{array}{c}\mathbf{0 . 5 0 2} * * * * \\
(2.600)\end{array}$ \\
\hline GRO & $\begin{array}{c}-\mathbf{0 . 0 8 6} * * * * \\
(-4.904)\end{array}$ & $\begin{array}{c}\mathbf{- 0 . 0 8 5} * * * \\
(-4.832)\end{array}$ \\
\hline Constant & $\begin{array}{c}\mathbf{4 . 8 1 9} * * * \\
(37.121)\end{array}$ & $\begin{array}{c}\mathbf{4 . 8 4 4} * * * * \\
(39.029)\end{array}$ \\
\hline $\begin{array}{l}\text { Observations } \\
\text { R-squared } \\
\text { Number of id }\end{array}$ & $\begin{array}{c}6,583 \\
0.358 \\
354\end{array}$ & $\begin{array}{c}6,583 \\
0.358 \\
354\end{array}$ \\
\hline
\end{tabular}

t-statistics in parentheses

Note: Significant levels “***”, “**” and “*” are referred to $\mathrm{p}<0.01, \mathrm{p}<0.05$ and $* \mathrm{p}<0.1$ respectively

After the replacement of explained variables, it came to a conclusion that the respective level of correlation towards the explanatory (DY and DPR) and the explained variable did not change accordingly. Meanwhile, the significance level of the control variable also failed to show a significant change, therefore, the relevant assumptions remained valid during the research, and it can be seen that the final conclusion of this study still have corresponding robustness. In other words, we believe that the yield of dividend is negatively associated to the price fluctuation of common stock. Meanwhile, the ratio of pay-out of dividend also negatively impacts the price fluctuation of respective common stock. 
Table 4.7: Summary of Hypothesis Results

\begin{tabular}{|c|c|c|c|}
\hline \multicolumn{4}{|l|}{ Summary of Hypothesis results } \\
\hline Hypothesis & Relationship & Significant level & Result \\
\hline $\begin{array}{l}\mathrm{H}_{1 \mathrm{a}} \text { : The yield of dividend is significantly correlated to the price fluctuation of common stock } \\
\text { of companies go public in HKEX. }\end{array}$ & Negative & $5 \%$ & Supported \\
\hline $\begin{array}{l}\mathrm{H}_{1 \mathrm{~b}} \text { : The yield of dividend is not significantly correlated to the price fluctuation of common } \\
\text { stock of companies go public in HKEX. }\end{array}$ & - & Nil & Unsupported \\
\hline $\begin{array}{l}\mathrm{H}_{2 \mathrm{a}} \text { : The pay-out ratio of dividend is significantly correlated to the price fluctuation of common } \\
\text { stock of companies go public in HKEX. }\end{array}$ & Negative & $5 \%$ & Supported \\
\hline $\begin{array}{l}\mathrm{H}_{2 \mathrm{~b}} \text { : The pay-out ratio of dividend is not significantly correlated to the price } \\
\text { fluctuation of common stock of companies go public in HKEX. }\end{array}$ & - & Nil & Unsupported \\
\hline $\begin{array}{l}\mathrm{H}_{3 \mathrm{a}} \text { : The size of enterprise is significantly correlated to the price fluctuation of common stock } \\
\text { of companies go public in HKEX. }\end{array}$ & Negative & $1 \%$ & Supported \\
\hline $\begin{array}{l}\mathrm{H}_{3 \mathrm{~b}} \text { : The size of enterprise is not significantly correlated to the price fluctuation of common } \\
\text { stock of companies go public in HKEX. }\end{array}$ & - & Nil & Unsupported \\
\hline $\begin{array}{l}\mathrm{H}_{4 \mathrm{a}} \text { : The leverage is significantly correlated to the price fluctuation of common stock of } \\
\text { companies go public in HKEX. }\end{array}$ & - & Nil & Unsupported \\
\hline $\begin{array}{l}\mathrm{H}_{4 b} \text { : The leverage is not significantly correlated to the price fluctuation of common stock of } \\
\text { companies go public in HKEX. }\end{array}$ & Positive & Nil & Supported \\
\hline $\begin{array}{l}\mathrm{H}_{5 \mathrm{a}} \text { : The volatility of earnings is significantly correlated to the price fluctuation of common } \\
\text { stock of companies go public in HKEX. }\end{array}$ & Positive & $1 \%$ & Supported \\
\hline $\begin{array}{l}\mathrm{H}_{5 b} \text { : The volatility of earnings is not significantly correlated to the price fluctuation of common } \\
\text { stock of companies go public in HKEX. }\end{array}$ & - & Nil & Unsupported \\
\hline $\begin{array}{l}\mathrm{H}_{6 a} \text { : The growth of asset is significantly correlated to the price fluctuation of common stock of } \\
\text { companies go public in HKEX. }\end{array}$ & - & Nil & Unsupported \\
\hline $\begin{array}{l}\mathrm{H}_{6 \mathrm{~b}} \text { : The growth of asset is not significantly correlated to the price fluctuation of common stock } \\
\text { of companies go public in HKEX. }\end{array}$ & Negative & Nil & Supported \\
\hline
\end{tabular}




\subsection{Discussion of Findings}

The research question is pointed out in Chapter One: What is the influence or impact that dividend policy may have on the price fluctuation of common stock particularly for companies go public in the stock market of Hong Kong?

4.7.1 The Correlation between the Yield of Dividend and the Price Fluctuation of Respective Common Stock

As shown in Table 4.7, in alignment with the academic studies in the past, Baskin (1989), Hashemijoo et al., (2012), Profilet and Bacon (2013), Ramadan (2013), Sew et al., (2015), Shah and Noreen (2016), Hamid et al., (2017), Zainudin et al., (2018) and Haque et al., (2019), the figures obviously supported with Hypothesis (H1a), and presented the price fluctuation of common stock in HKEX is somehow driven by the respective yield of dividend but in a negative direction, revealing any increase may have on in this yield would most probably and significantly lead to lower volatized price, mainly attributable to higher the yield of dividend led to a longer holding time of the stock investment and thereby reduce the fluctuations of common stock price. With the increase of a unit in the yield of dividend, the price fluctuation of respective common stock price will be decreased correspondingly. In the contrary, the statical outcomes concluded by Black and Scholes (1974), Allen and Rachim (1996), Hussainey et al., (2011), Nazir et al., (2010), AlShawawreh (2014), Anh and Nhi (2016) and Nguyen et al., (2020) appeared to be in disagreement with the outcomes of this paper.

4.7.2 The Correlation between the Pay-out Ratio of Dividend and the Price Fluctuation of Respective Common Stock

The statical outcomes which is supported with Hypothesis (H2a) and are consistent with the results from Baskin (1989), Allen and Rachim (1996), Nazir et al., (2010), Hussainey et al., (2011), Hashemijoo et al., (2012), Ramadan (2013), Lashgari and Ahmadi (2014), Al-Shawawreh (2014), Sew et al., (2015), Shah and Noreen (2016), Zainudin et al., (2018) and Nguyen et al., (2020), concluded the price of common stock would be volatized and driven by the respective pay-out ratio of dividend with a significant correlation existed in between but in a negative direction in the stock market of Hong Kong. This implies that the payout ratio of dividend would have a significantly influence on the price fluctuation of respective common stock. Any increase in the pay-out ratio of dividend can effectively suppress the respective price of common stock, mainly due to companies pay more cash dividends are most likely to attract more investors to invest or hold the stock for a longer period of time and hence lower the common stock price accordingly.

\subsubsection{The Correlation between Enterprise Size and the Price Fluctuation of Respective Common Stock}

To be supported with the Hypothesis (H3a) and the statiscal outcomes from Hussainey et al., (2011), Profilet and Bacon (2013), Anh and Nhi (2016), Sew et al., (2015), Zainudin et al., (2018) and Haque et al., (2019), our statical outcomes are outputted unanimously with them, presented the size of enterprise has a significant association to the price fluctuation of corresponding common stock but with a negative direction in HKEX, which indicated that larger enterprise size led to lower volatized price of common stock, mainly due to the 
investors pay more attention larger companies and more effective information reduce the speculative behavior in the capital market, and thus more stable stock price will be.

\subsubsection{The Correlation between Leverage and the Price Fluctuation of Respective Common Stock}

The statical results from Baskin (1989), Allen and Rachim (1996), Hussainey et al., (2011), Zakaria et al., (2012), Profilet and Bacon (2013), Sew et al., (2015) and Anh and Nhi (2016) found the leverage has significant association to the price fluctuation of respective common stock, which are in agreement with our Hypothesis (H4b), Although this control variable is considered an important fundamental factor of companies' financials and leverage is expected to fluctuate the price of common stock, no important influence is identified that the leverage has on the price fluctuation of respective common stock in HKEX, which may be due to the serious speculative behavior and herd effect of investors in Hong Kong stock market, caused lack of attention to fundamental information while investing into the stock. But interestingly, in disagreement with statical outcomes retrieved from Hashemijoo et al., (2012), Lashgari and Ahmadi (2014), Zainudin et al., (2018) and Nguyen et al., (2020).

4.7.5 The Correlation between the Volatility of Earnings and the Price Fluctuation of Respective Common Stock

Same with the primary statical outcomes from Baskin (1989), the statical outcomes in Table 4.7 presented the volatility of earnings has significantly correlation to the price fluctuation of corresponding common stock in the positive direction in HKEX, which supports Hypothesis (H5a), implying any increase in the volatility of earnings, the more volatilized and fluctuated the price of common stock would be, mainly attributable to the greater the volatility of earnings leads to smaller dividend payments to shareholders, resulting in more volatilized and fluctuated price of respective common stock. This is also in agreement with outcomes retrieved from the former hypothesis conducted by Allen and Rachim (1996), Hashemijoo et al., (2012), Sew et al., (2015) Zainudin et al., (2018) and Nguyen et al., (2020).

\subsubsection{The Correlation between Asset Growth and the Price Fluctuation of Respective Common Stock}

Since the primary statical study performed by Baskin (1989), and several followers, including Allen and Rachim (1996), Hussainey et al., (2011), Hashemijoo et al., (2012), Zakaria et al., (2012) and Sew et al., (2015) conducted similar studies, they all reached to a conclusion that the growth of asset has no correlation to the price fluctuation of respective common stock or drive the movement of it. With the chosen sample data obtained from the statical tools, our findings are supporting with Hypothesis (H6b) and these researchers. In spite of asset growth requires companies' continuous investment in itself with remaining cash after dividend paid to shareholders. As same as leverage, this control variable is considered an important fundamental factor of companies' financials, however, it is observed that asset growth has no significant influence on the price fluctuation of corresponding common stock or drives the movement of the price in HKEX, which may be due to the serious speculative behavior and herd effect of investors in Hong Kong stock market, caused lack of attention to fundamental information while investing into the stock. Nevertheless, Profilet and Bacon (2013) observed the growth of asset would affect and volatilize the price of respective common stock with a negative association found, and in the contrary, the statical outcomes 
from Lashgari and Ahmadi (2014) revealed the growth of asset would fluctuate and volatilize the price of common stock in a positive direction which is also in agreement with the outcomes retrieved from Zainudin et al., (2018) and Nguyen et al., (2020). 


\section{CHAPTER V: CONCLUSION AND RECOMMENDATION}

\subsection{Respective Conclusion and Recommendation}

To conclude, based on the sample data and tools being utilized in the study, to discover whether dividend policy would have impact or influence on the price fluctuation of common stock, as well as the possible correlation may exist in between, the results from it are showing not unanimous in the stock market of Hong Kong. This chapter includes conclusion of results, recommendations, research limitations and direction of future research.

\subsubsection{Conclusion of Results}

With the conceptualization by the theory being considered necessary to adopt to create the link between the policy or regulation of the company and respective price volatilization of the common stock, the theory of irrelevance of dividend is the first to understand since it pointed no particular relationship exists in between. By the level or relevance, the theory of bird-in-hand, signaling, cost of being agency, together with the theory of stakeholder as well as clientele effect are employed to the framework of literature prior to the research design. An empirical result on how the dividend policy impact or influence on the price fluctuation of respective common stock price is explained in detail in this paper.

Even since the study carried out by Black and Scholes (1974) who provided a primary reference for all later researchers studied the possible impact or influence that dividend policy may have on the price fluctuation of common stock, as well as Baskin (1989) indicated that the dividend policy proxied by the yield and the respective ratio of pay-out of dividend, has a significantly negative association to the price fluctuation of corresponding common stock, and provided a crucial analytical framework for related studied for later followers, the similar studies are being performed towards various sectors, markets and geographical locations including both developing and developed countries such as Malaysia and United States. Nevertheless, no consistent outcomes are being identified from all these empirical studies.

Hong Kong Stock Exchange, being the largest bourse worldwide when it comes to the size of market capitalization, HKEX is an official stock exchange based in Hong Kong, with 2,538 companies listed on HKEX as of the fiscal year end of 2020. In context to Hong Kong stock market, this study is the first study in terms of how the company's regulation or policy concerning dividend payment influences the price volatilization of respective common stock particularly towards companies which go public on HKEX in order to provide investors an important reference when making investment decisions.

The empirical findings supported the hypothesis that dividend policy which are proxied by the yield and the respective ratio of pay-out of dividend, is significantly correlated but in a negative way to the price fluctuation of respective common stock in Hong Kong stock market. This implies that the higher yield or pay-out ratio of dividend may possibly lead to lower price fluctuation of common stock. Moreover, the study revealed the enterprise size has a negative association to the price fluctuation of common stock price, in a positive way, the volatility of earnings is significantly associated to the price fluctuation of common 
stock. Nevertheless, both leverage and the growth rate of asset appealed insignificant to the price fluctuation of common stock in HKEX.

Therefore, this research concluded that particularly in the stock market of Hong Kong, a significant relationship exists between the enterprise's policy or regulation regarding dividend payment to its shareholders and the price fluctuation of respective common stock, more specifically, both the yield dividend would have significant impact and drive the price fluctuation of common stock based on the sample of chosen companies, this is the same as the ratio of pay-out of dividend as well.

\subsubsection{Recommendations}

Due to serious speculative behavior and herd effect of investors in the advanced stock market of Hong Kong in recent years, investors pay less attention to the fundamentals of listed companies when making investment decisions. Investors with different aims and investment expectations should have thorough understanding of the investment tools they employ. Especially for long-term and elder investors, or fund managers of retirement funds, to include stocks paying higher dividends are essential and thereby understanding how the enterprise's regulation or policy regarding dividend payment to its shareholders influences the price volatilization of common stock becomes necessary when considering adding such highdividend stocks. A significant negative relationship is observed and exists between the policy or regulation of dividend policy which is proxied by the yield of dividend and the pay-out ratio of dividend, and the price fluctuation of respective common stock particularly in Hong Kong stock market. Long-term investors are recommended to invest into the stock has higher the yield and the pay-out ratio of dividend to avoid higher potential on the volatility, while short-term investors are recommended to invest into stock with lower the yield and the pay-out ratio of dividend to maximize their potential gains in the stock market of Hong Kong. Investors with different investment goals and tenors could take advantage of this research when making investment decisions. However, the yield and the pay-out ratio of dividend may not be sufficiently representing the whole of dividend policy.

For listed companies in Hong Kong stock market, the findings of this research advise companies to sustain the dividend paid to investors at a higher level in order to maintain a lower level of the price fluctuation of common stock. In addition, the respective results also suggest the bigger enterprise size comes with lower the price fluctuation of respective common stock, while higher the volatility of earnings comes with higher volatility of common stock price. These is also to be considered during decision making of investment.

\subsection{Research Limitations}

In spite of that the data used in the research are deemed reliable by retrieving the data stream of WIND, the leading financial information service provider in China, providing accurate information to financial professionals, the related financial information is originally extracting from the audited financial statements mandatorily published on HKEX on a regular basis. Concerning the total sample size consists of 6,983 samples which is relatively large and the discrepancy in between is difficult to detect. This may lead to imprecise information in the analysis. 
In this research, 354 companies are identified to be sufficiently and significantly reflected the market conditions of Hong Kong stock market. However, financial institutions are excluded due to dissimilar format on account reporting standard and companies without long-term liabilities and missing essential data significant are also excluded in this study. In addition, there are 2,538 companies listed on HKEX as of the fiscal year end of 2020. The size of sample data may not reflect the whole picture of the stock market in Hong Kong.

The relevant research performed in the past concluded empirical results of how dividend policy proxied by two major independent variables, namely the dividend yield and the respective ratio of dividend pay-out, impacts or influences the price fluctuation of common stock in designated stock markets. Other qualitative factors related to the terms and conditions of dividend policy are totally omitted and they may possibly have influence on this research. This may mislead the empirical results.

\subsection{Direction of Future Research}

This paper serves as preliminary research to examine the relation between dividend policy proxied by two independent variables, the yield and the pay-out ratio of dividend with other control variables particularly on Hong Kong stock market. This research could be extended to the stock market of China as Shanghai Stock Exchange became the exchange with largest amount of Initial Public Offering ("IPO") in 2020 and Chinese companies listed on HKEX are accounting for a large portion with a gradually increasing trend. Also, the research coverage could be extended to other geographical locations as all researchers conducted similar studies found inconsistent empirical results on the stock market in developed and developing countries and the countries involved are concentrated to several which could not represent the whole.

Meanwhile, qualitative information is possibly involved in the research and it may provide wider scope and more significant findings. For instance, other factors such as terms and conditions of dividend policy that may also have influence on the price fluctuation of corresponding common stock to be considered and adopted as measured variables when performing data analysis. 


\section{REFERENCES}

1. Allen, D. E. and Rachim, V. S. (1996) Dividend policy and stock price volatility: Australian evidence. Applied Financial Economics. Vol. 6(2), pp.175-188.

2. Al-Malkawi, H.N. (2007) Determinants of corporate dividend policy in Jordan: an application of the Tobit model. Journal of Applied Accounting Research. Vol. 23, pp. 44-70.

3. Al-Shawawreh, F. K. (2014) The impact of dividend policy on share price volatility: Empirical evidence from Jordanian stock market. European Journal of Business and Management. Vol. 6(38), pp.133-143.

4. Anh, D.T.Q., \& Nhi, P.T.Y. (2016) The factors affect to the dividend policy of joint - stock companies listed on the Vietnam's Stock Market. In Vietnamese: Impact of dividend policy on stock price movements of companies listed on Vietnam's stock market. Journal of Development and Integration. Vol. 26(36).

5. Baskin, J. (1989) Dividend policy and the volatility of common stocks. The Journal of Portfolio Management. Vol. 15, pp.19-25.

6. Black, F., \& Scholes, M. (1974) The effects of dividend yield and dividend policy on common stock prices and returns. Journal of Financial Economics. Vol. 1, pp.1-22.

7. Black, F. (1976a) Studies of stock price volatility changes. Proceedings of the 1976 Meetings of the American Statistical Association, Business and Economics Section. Vol. 3(1-2), pp.177-181.

8. Black, F. (1976b) The dividend puzzle. The Journal of Portfolio Management. Vol. 2(2), pp.5-8.

9. Cheung, Y.W. and Ng, L.K. (1992) Stock price dynamics and firm size: an empirical investigation. The Journal of Finance. Vol. 47(5), pp.1985-1997.

10. Christie, A.A. (1982) The stochastic behaviour of common stock variances: value, leverage and interest rate effects. Journal of Financial Economics. Vol. 10(4), pp.407-432.

11. Gordon, M.J. and Shapiro, E. (1956) Capital equipment analysis: the required rate of profit. Management Science. Vol. 3, pp. 102-10.

12. Hamid, K., Khurram, M.U., \& Ghaffar, W. (2017) Juxtaposition of micro and macro dynamics of dividend policy on stock price volatility in financial sector of Pakistan: (comparative analysis through common, fixed, random and GMM effect). Journal of Accounting, Finance and Auditing Studies. Vol. 3(1), pp.64-79.

13. Hashemijoo, M., Ardekani, A. M., \& Younesi, N. (2012) The impact of dividend policy on share price volatility in the Malaysian Stock Market. Journal of Business Studies Quarterly. Vol. 4(1), pp.111129. 
14. Hussainey, K., Mgbame, C.O, \& ChijokeMgbame, A.M. (2011) Dividend policy and share price volatility: UK evidence. The Journal of Risk Finance. Vol. 12(1), pp.57-68.

15. Haque, R., Jahiruddin, A. T. M., \& Mishu, F. (2019) Dividend policy and share price volatility: A study on Dhaka Stock Exchange. Australian Academy of Accounting and Finance Review. Vol. 4(3), pp.8999.

16. HKEX (2020) History of HKEX and its Market. HKEX [online]. Available from: https://www.hkexgroup.com/About-HKEX/Company-Information/About-HKEX/History-of-HKEXand-its-Market?sc_lang=en [Accessed 26th October 2020].

17. James, C. (2020) Dividend Policy. Investopedia [Online]. Available from: https://www.investopedia.com/terms/d/dividendpolicy.asp [Accessed 9th August 2021].

18. Jensen, M. and Meckling, W. (1976) Theory of the firm: Managerial Behaviour, Agency Cost and Ownership Structure. Journal of Financial Economics. Vol. 3, No 4(4), pp.305-360.

19. Lashgari, D., \& Ahmadi, M. (2014) The impact of dividend policy on stock price volatility in the Tehran Stock Exchange. Kuwait Chapter of Arabian Journal of Business and Management Review. Vol. 3(10), pp.273-283.

20. Lewellen, W. G., Stanley, K. L., Lease, R. C., \& Schlarbaum, G. G. (1978) Some direct evidence on the dividend clientele phenomenon. The Journal of Finance. Vol. 33(5), pp.1385-1399.

21. Lintner, J. (1962) Dividends, earnings, leverage, stock prices and supply of capital to corporations. The Review of Economics and Statistics. Vol. 64, pp.243-69.

22. Miller, M.H., Modigliani, F. (1961) Dividend policy, growth, and the valuation of shares. The Journal of Business. Vol. 34, pp.411-433.

23. Nazir, M.S., Nawaz, M.M., Anwar, W., \& Ahmed, F. (2010) Determinants of stock price volatility in Karachi stock exchange: the mediating role of corporate dividend policy. International Research Journal of Finance and Economics. Vol. 55, pp.100-107.

24. Nguyen, T., Nguyen, H., Tran, Q., \& Le, Q. (2020) Dividend policy and share price volatility: empirical evidence from Vietnam. Accounting. Vol. 6, pp.67-78.

25. Nishat, M., \& Irfan, C. M. (2004) Dividend policy and stock price volatility in Pakistan. Paper presented at the PIDE-19th Annual General Meeting and Conference, Islamabad.

26. Petit, R.R. (1972) Dividend announcements, security performance, and capital market efficiency. Journal of Finance. Vol. 27, pp.993-1007.

27. Profilet, K. and Bacon, F. (2013) Dividend policy and stock price volatility in the U.S. equity capital market. Journal of Business and Behavioral Sciences. Vol. 25(2), pp.63-72. 
28. Ramadan, I.Z. (2013) Dividend policy and price volatility: empirical evidence from Jordan. International Journal of Academic Research in Accounting, Finance and Management Sciences. Vol. 3(2), pp.15-22.

29. Sadiq, M., Ahmad, S., Anjum, M.J., Suliman, M., Abrar, S.U. \& Khan, S.U.R. (2013) Stock price volatility in relation to dividend policy; A case study of Karachi Stock Market. Middle-East Journal of Scientific Research. Vol. 13(3), pp.426-431.

30. Schwert, G.W. (1989) Why does stock market volatility change over time? The Journal of Finance. Vol. 44(5), pp.1115-1153.

31. Sew, E.H., Albaity, M., \& Ibrahimy, A.I. (2015) Dividend policy and share price volatility. Investment Management and Financial Innovations. Vol. 12(1), pp.226-234.

32. Shah, S.A., \& Noreen, U. (2016) Stock price volatility and role of dividend policy: empirical evidence from Pakistan. International Journal of Economics and Financial Issues. Vol. 6(2), pp.461-472.

33. Zainudin, R., Mahdzan, N., \& Yet, C. (2018) Dividend policy and stock price volatility of industrial products firms in Malaysia. International Journal of Emerging Markets. Vol. 13(1), pp.203-217.

34. Zakaria, Z., \& Shamsuddin, S. (2012) Empirical evidence on the relationship between Stock Market Volatility and macroeconomics volatility in Malaysia. Journal of Business Studies Quarterly. Vol. 4(2), pp.61-71. 


\section{APPENDICES}

Appendix A - 354 listed companies in Hong Kong (samples of observation)

\begin{tabular}{|c|c|}
\hline Stock Code & Name \\
\hline 0001 & CKH HOLDINGS \\
\hline 0008 & PCCW \\
\hline 0010 & HANG LUNG GROUP \\
\hline 0012 & HENDERSON LAND \\
\hline 0014 & HYSAN DEV \\
\hline 0016 & SHK PPT \\
\hline 0017 & NEW WORLD DEV \\
\hline 0018 & ORIENTAL PRESS \\
\hline 0022 & MEXAN \\
\hline 0024 & BURWILL \\
\hline 0025 & CHEVALIER INT'L \\
\hline 0027 & GALAXY ENT \\
\hline 0028 & TIAN AN \\
\hline 0030 & BAN LOONG \\
\hline 0031 & CHINA AEROSPACE \\
\hline 0032 & CROSS-HAR \\
\hline 0034 & KOWLOON DEV \\
\hline 0035 & FE CONSORT INTL \\
\hline 0036 & FE HLDGS INTL \\
\hline 0038 & FIRST TRACTOR \\
\hline 0040 & GOLD PEAK \\
\hline 0043 & C.P. POKPHAND \\
\hline 0046 & COMPUTER \& TECH \\
\hline 0047 & HOP HING GROUP \\
\hline 0052 & FAIRWOOD HOLD \\
\hline 0053 & GUOCO GROUP \\
\hline 0055 & NEWAY GROUP \\
\hline 0057 & CHEN HSONG HOLD \\
\hline 0058 & SUNWAY INT'L \\
\hline 0059 & SKYFAME REALTY \\
\hline
\end{tabular}




\begin{tabular}{|c|c|}
\hline 0060 & HK FOOD INV \\
\hline 0069 & SHANGRI-LA ASIA \\
\hline 0075 & Y.T. REALTY \\
\hline 0081 & CH OVS G OCEANS \\
\hline 0082 & CRAZY SPORTS \\
\hline 0083 & SINO LAND \\
\hline 0084 & STELUX HOLDINGS \\
\hline 0085 & CE HUADA TECH \\
\hline 0087 & SWIRE PACIFIC B \\
\hline 0088 & TAI CHEUNG HOLD \\
\hline 0089 & TAI SANG LAND \\
\hline 0092 & CHAMPION TECH \\
\hline 0093 & TERMBRAY IND \\
\hline 0094 & GREENHEART GP \\
\hline 0097 & HENDERSON INV \\
\hline 0099 & WONG'S INT'L \\
\hline 0102 & SUMMIT ASCENT \\
\hline 0103 & SHOUGANG CENT \\
\hline 0104 & ASIA COMM HOLD \\
\hline 0105 & ASSO INT HOTELS \\
\hline 0106 & LANDSEA PPT \\
\hline 0107 & SICHUAN EXPRESS \\
\hline 0112 & LERTHAI GROUP \\
\hline 0113 & DICKSON CONCEPT \\
\hline 0116 & CHOW SANG SANG \\
\hline 0118 & COSMOS MACH \\
\hline 0119 & POLY PROPERTY \\
\hline 0123 & YUEXIU PROPERTY \\
\hline 0124 & GD LAND \\
\hline 0125 & SUN HING VISION \\
\hline 0126 & CARRIANNA \\
\hline 0129 & ASIA STANDARD \\
\hline 0135 & KUNLUN ENERGY \\
\hline 0136 & HENGTEN NET \\
\hline 0137 & JINHUI HOLDINGS \\
\hline
\end{tabular}




\begin{tabular}{|c|c|}
\hline 0138 & CCT FORTIS \\
\hline 0141 & SKYCHINAFORTUNE \\
\hline 0142 & FIRST PACIFIC \\
\hline 0143 & GUOAN INTL \\
\hline 0144 & CHINA MER PORT \\
\hline 0147 & IB SETTLEMENT \\
\hline 0148 & KINGBOARD HLDG \\
\hline 0149 & CH AGRI-PROD EX \\
\hline 0152 & SHENZHEN INT'L \\
\hline 0158 & MELBOURNE ENT \\
\hline 0163 & EMPEROR INT'L \\
\hline 0167 & IDT INT'L \\
\hline 0168 & TSINGTAO BREW \\
\hline 0173 & K. WAH INT'L \\
\hline 0175 & GEELY AUTO \\
\hline 0176 & SUPERACTIVE GP \\
\hline 0177 & JIANGSU EXPRESS \\
\hline 0178 & SA SA INT'L \\
\hline 0179 & JOHNSON ELEC H \\
\hline 0180 & KADER HOLDINGS \\
\hline 0182 & CONCORD NE \\
\hline 0184 & KECK SENG INV \\
\hline 0185 & ZENSUN ENT \\
\hline 0186 & NIMBLE HOLDINGS \\
\hline 0187 & JINGCHENG MAC \\
\hline 0191 & LAI SUN INT'L \\
\hline 0194 & LIU CHONG HING \\
\hline 0199 & ITC PROPERTIES \\
\hline 0201 & MAGNIFICENT \\
\hline 0205 & SEEC MEDIA \\
\hline 0207 & JOY CITY PPT \\
\hline 0210 & DAPHNE INT'L \\
\hline 0212 & NANYANG HOLD \\
\hline 0213 & NATIONAL ELEC H \\
\hline 0214 & ASIA ORIENT \\
\hline
\end{tabular}




\begin{tabular}{|c|c|}
\hline 0216 & CHINNEY INV \\
\hline 0219 & SHUNHO PROPERTY \\
\hline 0225 & POKFULAM \\
\hline 0229 & RAYMOND IND \\
\hline 0230 & MINMETALS LAND \\
\hline 0232 & CON AERO TECH \\
\hline 0234 & NEW CENTURY GP \\
\hline 0237 & SAFETY GODOWN \\
\hline 0239 & PAK FAH YEOW \\
\hline 0242 & SHUN TAK HOLD \\
\hline 0247 & TST PROPERTIES \\
\hline 0251 & SEA HOLDINGS \\
\hline 0255 & LUNG KEE \\
\hline 0256 & CITYCHAMP \\
\hline 0259 & YEEBO (INT'L H) \\
\hline 0262 & DESON DEV INT'L \\
\hline 0267 & CITIC \\
\hline 0269 & CRTG \\
\hline 0271 & ASIASEC PPT \\
\hline 0278 & WAH HA REALTY \\
\hline 0280 & KING FOOK HOLD \\
\hline 0281 & RIVERA (HOLD) \\
\hline 0286 & AIDIGONG \\
\hline 0292 & ASIA STD HOTEL \\
\hline 0293 & CATHAY PAC AIR \\
\hline 0297 & SINOFERT \\
\hline 0303 & VTECH HOLDINGS \\
\hline 0305 & WULING MOTORS \\
\hline 0306 & KWOON CHUNG BUS \\
\hline 0308 & CHINA TRAVEL HK \\
\hline 0316 & OOIL \\
\hline 0321 & TEXWINCA HOLD \\
\hline 0323 & MAANSHAN IRON \\
\hline 0328 & ALCO HOLDINGS \\
\hline 0332 & YUANHENG GAS \\
\hline
\end{tabular}




\begin{tabular}{|c|c|}
\hline 0333 & TOP FORM INT'L \\
\hline 0334 & CH DISPLAY OPT \\
\hline 0336 & HUABAO INTL \\
\hline 0338 & SHANGHAI PECHEM \\
\hline 0341 & CAFE DE CORAL H \\
\hline 0342 & NEWOCEAN ENERGY \\
\hline 0345 & VITASOY INT'L \\
\hline 0347 & ANGANG STEEL \\
\hline 0348 & CHINAHEALTHWISE \\
\hline 0355 & CENTURY C INT'L \\
\hline 0358 & JIANGXI COPPER \\
\hline 0363 & SHANGHAI IND H \\
\hline 0366 & LUKS GROUP (VN) \\
\hline 0367 & CHUANG'S INT'L \\
\hline 0369 & WING TAI PPT \\
\hline 0371 & BJ ENT WATER \\
\hline 0374 & FOUR SEAS MER \\
\hline 0375 & YGM TRADING \\
\hline 0377 & CHINA HUAJUN GP \\
\hline 0378 & FDG KINETIC \\
\hline 0383 & CHINA MED\&HCARE \\
\hline 0384 & CHINA GAS HOLD \\
\hline 0385 & CHINNEY ALLI \\
\hline 0391 & MEI AH ENTER \\
\hline 0392 & BEIJING ENT \\
\hline 0393 & GLORIOUS SUN \\
\hline 0398 & ORIENTAL WATCH \\
\hline 0403 & STARLITE HOLD \\
\hline 0406 & YAU LEE HOLD \\
\hline 0408 & YIP'S CHEMICAL \\
\hline 0411 & LAM SOON (HK) \\
\hline 0413 & SC HOLDINGS \\
\hline 0417 & TSE SUI LUEN \\
\hline 0419 & HUAYI TENCENT \\
\hline 0420 & FOUNTAIN SET \\
\hline
\end{tabular}




\begin{tabular}{|c|c|}
\hline 0432 & PCPD \\
\hline 0450 & HUNG HING PRINT \\
\hline 0451 & GCL NEWENERGY \\
\hline 0455 & TIANDA PHARMA \\
\hline 0458 & TRISTATE HOLD \\
\hline 0467 & UNITEDENERGY GP \\
\hline 0472 & NEW SILKROAD \\
\hline 0480 & HKR INT'L \\
\hline 0485 & CHINASINOSTAR \\
\hline 0487 & SUCCESSUNIVERSE \\
\hline 0488 & LAI SUN DEV \\
\hline 0493 & GOME RETAIL \\
\hline 0497 & CSI PROPERTIES \\
\hline 0498 & BLUE RIVER HLDG \\
\hline 0499 & QINGDAO HLDGS \\
\hline 0500 & FRONTIER SER \\
\hline 0506 & CHINA FOODS \\
\hline 0508 & DINGYI GP INV \\
\hline 0511 & TVB \\
\hline 0512 & CHINAGRANDPHARM \\
\hline 0513 & CONTINENTAL H \\
\hline 0517 & COSCO SHIP INTL \\
\hline 0518 & TUNGTEX (HOLD) \\
\hline 0522 & ASM PACIFIC \\
\hline 0525 & GUANGSHEN RAIL \\
\hline 0526 & CHINA AUTO NR \\
\hline 0529 & SIS INT'L \\
\hline 0532 & WKK INTL (HOLD) \\
\hline 0533 & GOLDLION HOLD \\
\hline 0535 & GEMDALE PPT \\
\hline 0539 & VICTORY CITY \\
\hline 0547 & DIGITAL DOMAIN \\
\hline 0551 & YUE YUEN IND \\
\hline 0554 & HANS ENERGY \\
\hline 0559 & DETAI NEWENERGY \\
\hline
\end{tabular}




\begin{tabular}{|c|c|}
\hline 0563 & SH IND URBAN \\
\hline 0570 & TRAD CHI MED \\
\hline 0576 & ZHEJIANGEXPRESS \\
\hline 0578 & ROSAN RES \\
\hline 0590 & LUK FOOK HOLD \\
\hline 0593 & DREAMEAST \\
\hline 0603 & CHINA OIL \& GAS \\
\hline 0610 & WAI KEE HOLD \\
\hline 0613 & PLANETREE INT'L \\
\hline 0617 & PALIBURG HOLD \\
\hline 0632 & CHK OIL \\
\hline 0638 & KIN YAT HOLD \\
\hline 0641 & CHTC FONG'S INT \\
\hline 0660 & WAI CHUN BIOTEC \\
\hline 0669 & TECHTRONIC IND \\
\hline 0675 & K \& P INT'L \\
\hline 0677 & GOLDEN RES DEV \\
\hline 0680 & NAN HAI CORP \\
\hline 0683 & KERRY PPT \\
\hline 0685 & MEDIA CHINESE \\
\hline 0688 & CHINA OVERSEAS \\
\hline 0693 & TAN CHONG INT'L \\
\hline 0701 & CNT GROUP \\
\hline 0710 & BOE VARITRONIX \\
\hline 0711 & ASIA ALLIED INF \\
\hline 0713 & WORLD HOUSEWARE \\
\hline 0715 & CHINA OCEANWIDE \\
\hline 0716 & SINGAMAS CONT \\
\hline 0718 & TAI UNITED HOLD \\
\hline 0719 & SHANDONG XINHUA \\
\hline 0723 & RELIANCE GLO HL \\
\hline 0725 & PERENNIAL INT'L \\
\hline 0727 & CROWNICORP \\
\hline 0731 & SAMSON PAPER \\
\hline 0732 & TRULY INT'L \\
\hline
\end{tabular}




\begin{tabular}{|c|c|}
\hline 0738 & LE SAUNDA \\
\hline 0747 & SHENYANG PUBLIC \\
\hline 0752 & PICO FAR EAST \\
\hline 0754 & HOPSON DEV HOLD \\
\hline 0755 & SHANGHAI ZENDAI \\
\hline 0758 & MACROLINK CAP \\
\hline 0759 & CEC INT'L HOLD \\
\hline 0765 & PERFECTECH INTL \\
\hline 0769 & CHINA RAREEARTH \\
\hline 0771 & AUTOMATED SYS \\
\hline 0855 & CHINA WATER \\
\hline 0862 & VISION VALUES \\
\hline 0874 & BAIYUNSHAN PH \\
\hline 0876 & KAISA HEALTH \\
\hline 0878 & SOUNDWILL HOLD \\
\hline 0882 & TIANJIN DEV \\
\hline 0894 & MAN YUE TECH \\
\hline 0897 & WAI YUEN TONG \\
\hline 0898 & MULTIFIELD INTL \\
\hline 0902 & HUANENG POWER \\
\hline 0907 & ELEGANCEOPTICAL \\
\hline 0910 & CHINA SANDI \\
\hline 0914 & CONCH CEMENT \\
\hline 0921 & HISENSE HA \\
\hline 0922 & ANXIANYUAN CH \\
\hline 0934 & SINOPEC KANTONS \\
\hline 0938 & MAN SANG INT'L \\
\hline 0941 & CHINA MOBILE \\
\hline 0959 & CENTURY ENT INT \\
\hline 0970 & SPARKLE ROLL \\
\hline 0978 & CHI MER LAND \\
\hline 0983 & SOCAM DEV \\
\hline 0984 & AEON STORES \\
\hline 0986 & CH ENV ENERGY \\
\hline 0987 & CH RENEW EN INV \\
\hline
\end{tabular}




\begin{tabular}{|c|c|}
\hline 0988 & SILKROAD LOG \\
\hline 0989 & HUA YIN INTL H \\
\hline 0990 & THEME INT'L \\
\hline 0991 & DATANG POWER \\
\hline 0992 & LENOVO GROUP \\
\hline 0995 & ANHUIEXPRESSWAY \\
\hline 0996 & CARNIVAL GROUP \\
\hline 1001 & HK SH ALLIANCE \\
\hline 1004 & C SMARTERENERGY \\
\hline 1005 & MATRIX HOLDINGS \\
\hline 1033 & SINOPEC SSC \\
\hline 1036 & VANKE OVERSEAS \\
\hline 1037 & MAXNERVA TECH \\
\hline 1038 & CKI HOLDINGS \\
\hline 1043 & COSLIGHT TECH \\
\hline 1044 & HENGAN INT'L \\
\hline 1045 & APT SATELLITE \\
\hline 1046 & UNIVERSE ENT \\
\hline 1047 & NGAI HING HONG \\
\hline 1049 & CELESTIAL ASIA \\
\hline 1050 & KARRIE INT'L \\
\hline 1052 & YUEXIUTRANSPORT \\
\hline 1053 & CHONGQING IRON \\
\hline 1055 & CHINA SOUTH AIR \\
\hline 1059 & KANTONE HOLDING \\
\hline 1060 & ALI PICTURES \\
\hline 1063 & SUNCORP TECH \\
\hline 1064 & ZHONG HUA INT'L \\
\hline 1065 & TIANJIN CAPITAL \\
\hline 1070 & TCL ELECTRONICS \\
\hline 1071 & HUADIAN POWER \\
\hline 1072 & DONGFANG ELEC \\
\hline 1079 & PINE TECH \\
\hline 1093 & CSPC PHARMA \\
\hline 1097 & I-CABLE COMM \\
\hline
\end{tabular}




\begin{tabular}{|c|c|}
\hline 1098 & ROAD KING INFRA \\
\hline 1104 & APAC RESOURCES \\
\hline 1105 & SING TAO \\
\hline 1109 & CHINA RES LAND \\
\hline 1114 & BRILLIANCE CHI \\
\hline 1118 & GOLIK HOLDINGS \\
\hline 1120 & ARTS OPTICAL \\
\hline 1122 & QINGLING MOTORS \\
\hline 1123 & CHINA-HK PHOTO \\
\hline 1124 & COASTAL GL \\
\hline 1125 & LAI FUNG HOLD \\
\hline 1131 & AGRITRADE RES \\
\hline 1132 & ORANGE SKY G H \\
\hline 1133 & HARBIN ELECTRIC \\
\hline 1137 & HK TECH VENTURE \\
\hline 1138 & COSCO SHIP ENGY \\
\hline 1159 & STARLIGHT CUL \\
\hline 1166 & SOLARTECH INT'L \\
\hline 1168 & SINOLINK HOLD \\
\hline 1170 & KINGMAKER \\
\hline 1171 & YANZHOU COAL \\
\hline 1172 & MAGNUSCONCORDIA \\
\hline 1173 & VEEKO INT'L \\
\hline 1176 & ZHUGUANG HOLD \\
\hline 1180 & PARADISE ENT \\
\hline 1184 & S.A.S. DRAGON \\
\hline 1185 & CHINA ENERGINE \\
\hline 1189 & GBA DYNAMIC \\
\hline 1192 & TITAN PETROCHEM \\
\hline 1193 & CHINA RES GAS \\
\hline 1196 & REALORD GROUP \\
\hline 1199 & COSCO SHIP PORT \\
\hline 1200 & MIDLAND HOLDING \\
\hline 1201 & TESSON HOLDINGS \\
\hline 1203 & GUANGNAN (HOLD) \\
\hline
\end{tabular}




\begin{tabular}{|c|c|}
\hline 1205 & CITIC RESOURCES \\
\hline 1207 & SRE GROUP \\
\hline 1208 & MMG \\
\hline 1218 & EASYKNIT INT'L \\
\hline 1220 & ZHIDAO INT'L \\
\hline 1221 & SINO HOTELS \\
\hline 1222 & WANG ON GROUP \\
\hline 1223 & SYMPHONY HOLD \\
\hline 1224 & C C LAND \\
\hline
\end{tabular}

